\title{
Synthesis, Characterisation and Antiproliferative Studies of Allyl(dicarbonyl)(cyclopentadienyl)molybdenum Complexes and Cyclodextrin Inclusion Compounds
}

\author{
Susana S. Braga, ${ }^{*[a]}$ Vijaya Mokal, ${ }^{[b]}$ Filipe A. Almeida Paz, ${ }^{[c]}$ \\ Martyn Pillinger, ${ }^{[\mathrm{c}]}$ Ana F. Branco, ${ }^{[\mathrm{d}]}$ Vilma A. Sardão, ${ }^{[\mathrm{d}]}$ \\ Cátia V. Diogo, ${ }^{[d]}$ Paulo J. Oliveira, ${ }^{\text {[d] }}$ Maria P. M. Marques, ${ }^{\text {[e] }}$ \\ Carlos C. Romão, ${ }^{[b]}$ and Isabel S. Gonçalves*[c]
}

Keywords: Molybdenum / Half-sandwich complexes / Cyclodextrins / Inclusion compounds / Antitumor agents

The complexes $\left[\left(\eta^{5}-\mathrm{C}_{5} \mathrm{H}_{4}-\mathrm{CO}-\mathrm{R}\right) \mathrm{Mo}(\mathrm{CO})_{2}\left(\eta^{3}-\mathrm{C}_{3} \mathrm{H}_{5}\right)\right][\mathrm{R}=\mathrm{OH}$ (1), Phe-OMe (2)] have been examined as guests for the cyclodextrin (CD) hosts $\beta-\mathrm{CD}$ and heptakis(2,3,6-tri-Omethyl)- $\beta$-CD (TRIMEB), and the resultant inclusion compounds have been characterised in the solid state by elemental and thermogravimetric analyses, powder X-ray diffraction, ${ }^{13} \mathrm{C}\left\{{ }^{1} \mathrm{H}\right\}$ cross-polarisation $(\mathrm{CP})$ magic angle spinning (MAS) NMR spectroscopy and FTIR spectroscopy. Singlecrystal X-ray analysis of $\mathbf{1}$ shows that the unit cell contains centrosymmetric supramolecular dimers comprising two di- carbonyl complexes linked through hydrogen-bonding interactions involving the carboxylic acid groups. In screening tests for antiproliferative effects, the CD adducts containing 1 displayed enhanced antitumour activity against mouse melanoma (when compared with nonincluded 1), while showing minimal activity towards human adenocarcinoma and nontumour rat myoblast cell lines. TRIMEB encapsulation resulted in a predominant toxic effect on tumour cells versus the non-neoplastic myoblast cells.

\section{Introduction}

In 1963, Cousins and Green reported the synthesis of $\left[\mathrm{CpMo}(\mathrm{CO})_{2}\left(\eta^{3}-\mathrm{C}_{3} \mathrm{H}_{5}\right)\right]$ by $\mathrm{UV}$ irradiation of $\left[\mathrm{CpMo}(\mathrm{CO})_{3^{-}}\right.$ $\left.\left(\eta^{1}-\mathrm{C}_{3} \mathrm{H}_{5}\right)\right]$, which was prepared by reaction of the sodium salt $\mathrm{Na}\left[\mathrm{CpMo}(\mathrm{CO})_{3}\right]$ with an excess amount of allyl chloride $\left(\mathrm{Cp}=\eta^{5}-\mathrm{C}_{5} \mathrm{H}_{5}\right) \cdot{ }^{[1]} \mathrm{A}$ few years later, King noted that solutions of the $\pi$-allyl complex exhibited four metal-carbonyl stretching bands and concluded that two different species existed in solution. ${ }^{[2]}$ Davison, ${ }^{[3]}$ Faller $^{[4]}$ and their coworkers correctly identified these species as the endo and exo isomers, which can interconvert by a mechanism equiv-

[a] QOPNA, Department of Chemistry, University of Aveiro, Campus Universitário de Santiago, 3810-193 Aveiro, Portugal E-mail:sbraga@ua.pt http://www.ua.pt/qopna/PageText.aspx?id=17401

[b] Instituto de Tecnologia Química e Biológica da Universidade Nova de Lisboa,

Av. da República, Estação Agronómica Nacional, 2780-157 Oeiras, Portugal

[c] Department of Chemistry, CICECO, University of Aveiro, Campus Universitário de Santiago, 3810-193 Aveiro, Portugal E-mail: E-mail:igoncalves@ua.pt http://www.ciceco.ua.pt/IsabelGoncalves

[d] Center for Neuroscience and Cell Biology, University of Coimbra, 3004-517 Coimbra, Portugal

[e] "Molecular Physical-Chemistry" R\&D Group, Department of Life Sciences, Faculty of Science and Technology, University of Coimbra,

P. O. Box 3046, 3001-401 Coimbra, Portugal alent to rotation of the planar $\pi$-allyl moiety about a molybdenum-allyl axis. At the same time, an improved synthesis of $\left[\mathrm{CpMo}(\mathrm{CO})_{2}\left(\eta^{3}-\mathrm{C}_{3} \mathrm{H}_{5}\right)\right]$ was reported based on the replacement of acetonitrile and chlorido ligands in $\left[\left(\eta^{3}-\mathrm{C}_{3} \mathrm{H}_{5}\right) \mathrm{Mo}(\mathrm{CO})_{2}\left(\mathrm{CH}_{3} \mathrm{CN}\right)_{2} \mathrm{Cl}\right]$ by the cyclopentadienyl ligand. ${ }^{[5]}$ By using this method, complexes with inden$y 1,{ }^{[6]}$ fluorenyl, ${ }^{[7]}$ dibenzo[ $[c, g]$ fluorenyl, ${ }^{[8]}$ cyclopenta[ $[l]-$ phenanthrenyl ${ }^{[9]}$ and cyclopentadienyl ligands substituted with trimethylsilyl groups $\left[\eta^{5}-\mathrm{C}_{5} \mathrm{H}_{4} \mathrm{SiMe}_{3}, \eta^{5}-\mathrm{C}_{5} \mathrm{H}_{3}-\right.$ $\left.\left(\mathrm{SiMe}_{3}\right)_{2}\right]^{[10,11]}$ and a carboxylic ester function $\left(\eta^{5}\right.$ $\left.\mathrm{C}_{5} \mathrm{H}_{4} \mathrm{COOMe}\right)^{[11]}$ were obtained.

$\eta^{3}$-Allyl(dicarbonyl)(cyclopentadienyl)molybdenum(II) complexes have been intensively studied, both experimentally and theoretically, to better understand their conformational preferences and endo-exo interconversion in different media. ${ }^{[12]}$ Practical uses of these complexes have mainly focused on their use as starting materials for the preparation of mixed ring and indenyl analogues of molybdenocene and tungstenocene. ${ }^{[7,9,11,13]}$ For example, protonation of $\left[\mathrm{Cp}^{\prime} \mathrm{Mo}(\mathrm{CO})_{2}\left(\eta^{3}-\mathrm{C}_{3} \mathrm{H}_{5}\right)\right]\left(\mathrm{Cp}^{\prime}=\right.$ substituted $\left.\mathrm{Cp}\right)$ with $\mathrm{HBF}_{4}$ followed by cyclopentadiene coordination gives $\eta^{4}$-cyclopentadiene complexes. Complexes with the $\mathrm{CpCp}^{\prime} \mathrm{Mo}$ moiety are then available through oxidative, reductive or photochemical pathways. ${ }^{[7,13 \mathrm{a}]}$ The $\mathrm{Mo}^{\mathrm{II}}$-allyl complexes are also useful in organic synthesis because functional groups adjacent to the $\eta^{3}$-allyl group can be transformed with excellent stereoselectivity and regioselectivity. ${ }^{[14]}$ More recently, we 
and others have shown that the complexes $\left[\mathrm{Cp}^{\prime} \mathrm{Mo}(\mathrm{CO})_{2^{-}}\right.$ $\left.\left(\eta^{3}-\mathrm{C}_{3} \mathrm{H}_{5}\right)\right]$ (with $\mathrm{Cp}^{\prime}=\mathrm{Cp}, \eta^{5}-\mathrm{C}_{5} \mathrm{H}_{4} \mathrm{Me}$ and $\eta^{5}-\mathrm{C}_{5} \mathrm{Me}_{5},{ }^{[15]}$ or cyclopentadienyl bearing a chiral oxazoline pendant group ${ }^{[16]}$ ) can be used as catalyst precursors for the epoxidation of olefins, with tert-butylhydroperoxide or hydrogen peroxide as oxidant. Under the reaction conditions, these complexes undergo oxidative decarbonylation in situ (by reaction with the oxidant) to give the actual $\mathrm{Mo}^{\mathrm{VI}}$ catalysts. Molybdenum $\eta^{3}$-allyldicarbonyl complexes also have a good potential for biomedical applications, either as infrared labels for amino acids and peptides ${ }^{[17]}$ or as cytotoxic agents. ${ }^{[18]}$

In 2000 we reported the synthesis and characterisation of $\beta$-cyclodextrin (CD) inclusion compounds of [ $\mathrm{Cp}^{\prime} \mathrm{Mo}-$ $\left.(\mathrm{CO})_{2}\left(\eta^{3}-\mathrm{C}_{3} \mathrm{H}_{5}\right)\right]$ derivatives $\left(\mathrm{Cp}^{\prime}=\mathrm{Cp}, \eta^{5}-\mathrm{C}_{5} \mathrm{H}_{4} \mathrm{SiMe}_{3}\right.$, indenyl). ${ }^{[10]} \mathrm{CDs}$ are cyclic oligosaccharides that can function as second-sphere ligands toward many transition-metal complexes and organometallic compounds. ${ }^{[19]}$ Indeed, subsequent to the above report, various other types of cyclopentadienylmolybdenum-carbonyl complexes were successfully encapsulated, not only in native (unmodified) $\beta-C D$ but also in methylated derivatives. ${ }^{[20-24]}$ These host-guest systems were mainly studied in catalytic olefin epoxidation. ${ }^{[20 a, 21,22]}$ However, another very interesting use may be as delivery systems of organometallic pharmaceuticals. For example, association of $\left[\mathrm{CpMo}\left(2,2^{\prime}\right.\right.$-biimidazole $\left.)(\mathrm{CO})_{2}\right]-$ $\left(\mathrm{BF}_{4}\right)$ with heptakis(2,6-di- $O$-methyl)- $\beta$-CD (DIMEB) led to an enhanced antiproliferative effect against K1735-M2 mouse melanoma cells. ${ }^{[24]}$ The use of CDs in pharmaceutical formulations can help to enhance the solubility, stability, activity and bioavailability of drug molecules, ${ }^{[25]}$ mask odours and tastes, ${ }^{[26]}$ control drug-release profiles, ${ }^{[27]}$ alleviate toxicity, ${ }^{[28]}$ and modulate drug permeability in topical applications. ${ }^{[29]}$ In the present work, the acid $\left[\left(\eta^{5}-\mathrm{C}_{5} \mathrm{H}_{4}\right.\right.$ $\left.\mathrm{COOH}) \mathrm{Mo}(\mathrm{CO})_{2}\left(\eta^{3}-\mathrm{C}_{3} \mathrm{H}_{5}\right)\right]$ (1) and the phenylalanine derivative $\left[\left(\eta^{5}-\mathrm{C}_{5} \mathrm{H}_{4}-\mathrm{CO}-\mathrm{Phe}-\mathrm{OMe}\right) \mathrm{Mo}(\mathrm{CO})_{2}\left(\eta^{3}-\mathrm{C}_{3} \mathrm{H}_{5}\right)\right]$ (2) (Scheme 1) have been examined as guests for $\beta-C D$ and heptakis(2,3,6-tri- $O$-methyl)- $\beta$-CD (TRIMEB), and the resultant inclusion compounds have been characterised in the solid state by using various techniques. The pure complexes and the $\mathrm{CD}$ adducts were screened for their growth-inhibition activity against mouse melanoma and human adenocarcinoma cell lines, and a nontumour rat myoblast line.
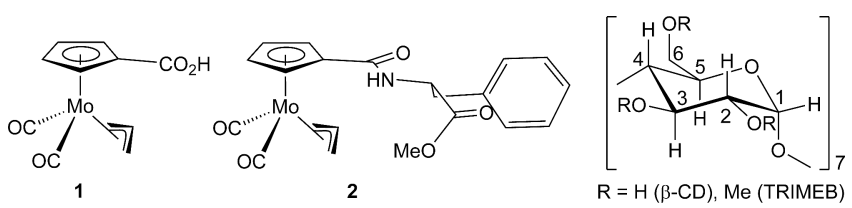

Scheme 1. Guests and hosts used in this work.

\section{Results and Discussion}

\section{Synthesis and Characterisation}

\section{Guest Complexes}

The carboxylic acid $\mathbf{1}$ and phenylalanine $\mathbf{2}$ derivatives (Scheme 1) were prepared as described previously. ${ }^{[17]}$ Acid
1 was obtained from the reaction of $\left[\mathrm{CpMo}(\mathrm{CO})_{2}\left(\eta^{3}-\right.\right.$ $\left.\mathrm{C}_{3} \mathrm{H}_{5}\right)$ ] with $\mathrm{BuLi}$ and solid $\mathrm{CO}_{2}$ followed by aqueous workup. Coupling of $\mathbf{1}$ to L-phenylalanine methyl ester gave the amino acid derivative $\mathbf{2}$. Complex $\mathbf{2}$ was obtained in the present work as a microcrystalline powder and was characterised by powder X-ray diffraction (PXRD) in addition to FTIR spectroscopy and ${ }^{13} \mathrm{C}\left\{{ }^{1} \mathrm{H}\right\}$ cross-polarisation $(\mathrm{CP})$ magic angle spinning (MAS) NMR spectroscopy (details in the following subsection). The experimental PXRD pattern of bulk 2 shows a pure monophasic material and the comparison of the pattern with a simulated one calculated from the cell parameters and atomic coordinates reported previously for crystals of $\mathbf{2}^{[17]}$ shows that the two materials are isostructural (Figure 1).

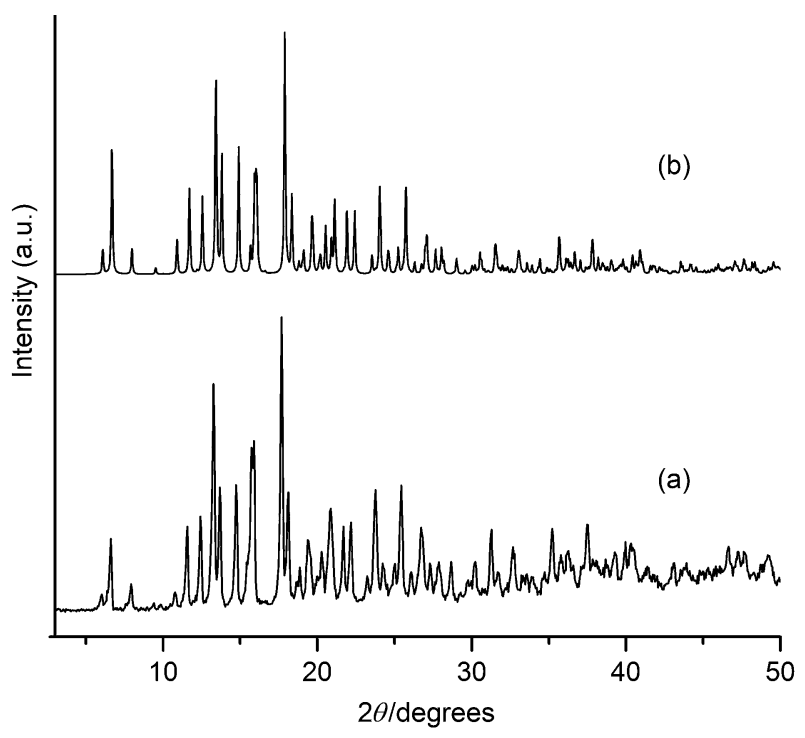

Figure 1. (a) Experimental and (b) simulated PXRD patterns of complex 2. The program Mercury (Copyright CCDC, ver. 3.1 ${ }^{[30]}$ was used to calculate the simulated pattern from the single-crystal $\mathrm{X}$-ray data published for 2 . $^{[17]}$

Single crystals of complex 1 suitable for X-ray diffraction were obtained. Even though the synthesis of $\mathbf{1}$ was described more than a decade ago, ${ }^{[17]}$ its crystal structure has remained elusive. A search in the literature and in the Cambridge Structural Database (version 5.34, November 2012, with three updates) ${ }^{[31]}$ shows, however, that crystallographic studies for a number of $\left[\mathrm{Cp}^{\prime} \mathrm{Mo}(\mathrm{CO})_{2}\left(\eta^{3}-\mathrm{C}_{3} \mathrm{H}_{5}\right)\right]$ derivatives have already been described by various research groups: $\mathrm{Cp}^{\prime}=\mathrm{Cp}$ by Faller et al., ${ }^{[32]} \eta^{5}-\mathrm{C}_{5} \mathrm{H}_{4}-\mathrm{COOMe}$ by Vanarsdale and Kochi, ${ }^{[33]} \eta^{5}-\mathrm{C}_{5} \mathrm{H}_{4}-\mathrm{CO}-\mathrm{Phe}-\mathrm{OMe}$ by van Staveren et al., ${ }^{[17]} \eta^{5}-\mathrm{C}_{5} \mathrm{H}_{4}-\mathrm{COOMe}$ by Honzíček et al., ${ }^{[11]}$ $\eta^{5}-\mathrm{C}_{5} \mathrm{H}_{4} \mathrm{Me}$ and $\eta^{5}-\mathrm{C}_{5} \mathrm{Me}_{5}$ by Neves et al., ${ }^{[15]}$ a cyclopentadienyl ligand bearing a chiral oxazoline pendant group by Reis et al., ${ }^{[16]}$ and $\eta^{5}-\mathrm{C}_{5} \mathrm{H}_{3}(\mathrm{CONH} t \mathrm{Bu})_{2}$ by Honzíček et al. ${ }^{[34]}$

Complex 1 crystallises in the centrosymmetric monoclinic space group $P 2_{1} / c$ with the asymmetric unit being composed of a whole $\left[\left(\eta^{5}-\mathrm{C}_{5} \mathrm{H}_{4}-\mathrm{COOH}\right) \mathrm{Mo}(\mathrm{CO})_{2}\right.$ $\left.\left(\eta^{3}-\mathrm{C}_{3} \mathrm{H}_{5}\right)\right]$ molecular unit as depicted in Figure 2. The com- 
plex has the molybdenum centre coordinated to two carbonyl $(\mathrm{C} \equiv \mathrm{O})$ groups, one substituted cyclopentadienyl ring and one allyl ligand. Notably, the allyl ligand is coordinated by means of a typical exo conformation, quite similar to that reported for the $\eta^{5}-\mathrm{C}_{5} \mathrm{H}_{4} \mathrm{Me}$ and $\eta^{5}-\mathrm{C}_{5} \mathrm{Me}_{5}$ derivatives. ${ }^{[15]}$ According to the assumptions of Faller et al., ${ }^{[32]}$ this isomer is the most energetically favourable in the solid state, and appears in a common fashion for a number of related complexes. ${ }^{[11,15,33,34]}$ The endo conformation for the allyl ligand is much rarer. Nevertheless, it was first observed in the crystal structure of $\mathbf{2}$, reported by Staveren et al., ${ }^{[17]}$ and later found in a complex described by Reis et al., ${ }^{[16]}$ with relatively large substituent groups on the $\mathrm{Cp}$ ring. In 1, the average dihedral angle between the mean plane containing the exo $\eta^{3}$-allyl group and the substituted $\mathrm{Cp}$ ring is $33.7(4)^{\circ}$, a value that agrees well with those found in the aforementioned complexes exhibiting the same conformation for this ligand. ${ }^{[11,15,33,34]}$

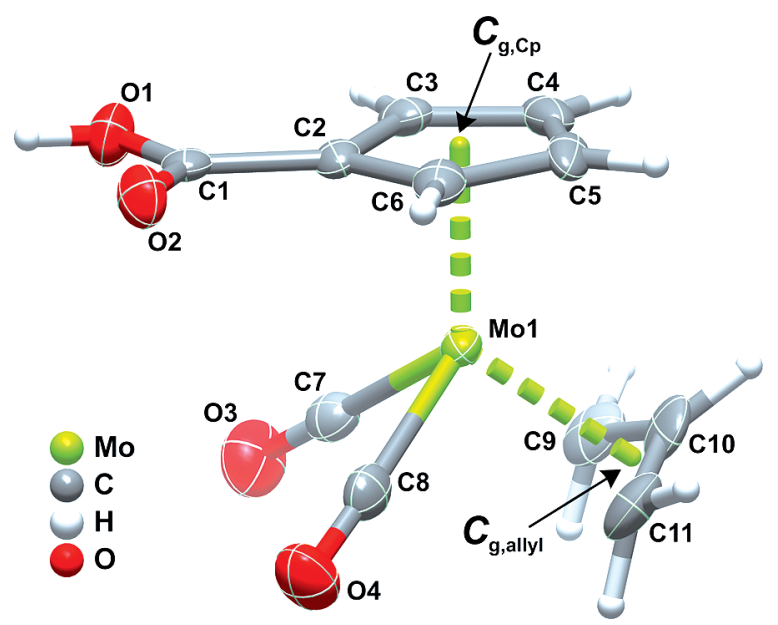

Figure 2. Schematic representation of the crystal structure of $\left[\left(\eta^{5}-\mathrm{C}_{5} \mathrm{H}_{4}-\mathrm{COOH}\right) \mathrm{Mo}(\mathrm{CO})_{2}\left(\eta^{3}-\mathrm{C}_{3} \mathrm{H}_{5}\right)\right]$ (1) showing the labelling scheme for all non-hydrogen atoms. Thermal ellipsoids are drawn at the $60 \%$ probability level and hydrogen atoms are represented as small spheres with arbitrary radii. Mo-C bonds to the $\mathrm{Cp}^{\prime}$ and $\eta^{3}$-allyl organic ligands have been replaced by green dashed bonds to the corresponding centroids $\left(C_{\mathrm{g}, \mathrm{Cp}}\right.$ and $\left.C_{\mathrm{g}, \text { allyl }}\right)$. Only one position of the hydrogen atom belonging to the carboxylic acid group is represented. For selected bond lengths and angles, see Table 1.

By replacing the Mo-C bonds to the $\eta^{3}$-allyl and $\eta^{5}$ $\mathrm{C}_{5} \mathrm{H}_{4}-\mathrm{COOH}$ ligands (see Table 1 for individual geometrical details) by a single connection to the corresponding centres of gravity $\left(C_{\mathrm{g}, \text { allyl }}\right.$ and $C_{\mathrm{g}, \mathrm{Cp}}$, respectively), the overall coordination geometry of the metal centre can be envisaged as a highly distorted tetrahedron. Such geometry is typical of the class of three-legged piano-stool complexes to which this complex belongs. Even though the calculated interaction distances are all relatively similar, all being found in the 1.947(3)-2.053(2) Å range, the internal tetrahedral angles clearly reflect the different chemical nature of each coordinated ligand, with values ranging from $78.28(11)^{\circ}$ to $125.95(2)^{\circ}$ (Table 1$)$.
Table 1. Selected bond lengths $[\AA]$ and angles $\left[^{\circ}\right]$ for the molybdenum coordination environment present in the crystals of complex $\left[\left(\eta^{5}-\mathrm{C}_{5} \mathrm{H}_{4}-\mathrm{COOH}\right) \mathrm{Mo}(\mathrm{CO})_{2}\left(\eta^{3}-\mathrm{C}_{3} \mathrm{H}_{5}\right)\right](\mathbf{1}) \cdot{ }^{[a, b]}$

\begin{tabular}{|c|c|c|c|}
\hline Mo1-C2 & $2.289(2)$ & $C_{\mathrm{g}, \mathrm{Cp}}-\mathrm{Mol}-\mathrm{C} 7$ & $121.82(2)$ \\
\hline Mo1-C3 & $2.333(2)$ & $C_{\mathrm{g}, \mathrm{Cp}}-\mathrm{Mol}-\mathrm{C} 8$ & $123.00(2)$ \\
\hline Mo1-C4 & $2.385(3)$ & $C_{\mathrm{g}, \mathrm{Cp}}^{\mathrm{g}} \cdots \mathrm{Mo} 1 \cdots C_{\mathrm{g}, \text { allyl }}$ & $125.95(2)$ \\
\hline Mo1-C5 & $2.396(3)$ & $\mathrm{C} 7-\mathrm{Mo1}-\mathrm{C} 8$ & $78.28(11)$ \\
\hline Mo1-C6 & $2.339(2)$ & C7-Mol- $-C_{\mathrm{g}, \text { allyl }}$ & $97.57(2)$ \\
\hline Mo1-C7 & $1.947(3)$ & C8-Mol- $-C_{\mathrm{g}, \text { allyl }}$ & $98.40(2)$ \\
\hline Mo1-C8 & $1.952(3)$ & & \\
\hline Mo1-C9 & $2.341(3)$ & & \\
\hline Mo1-C10 & $2.224(3)$ & & \\
\hline Mo1-C11 & $2.337(3)$ & & \\
\hline Mol $\cdots C_{\mathrm{g}, \mathrm{Cp}}$ & $2.0176(12)$ & & \\
\hline Mol $\cdots C_{\mathrm{g}, \text { allyl }}$ & $2.053(2)$ & & \\
\hline
\end{tabular}

[a] $C_{\mathrm{g}, \mathrm{Cp}}$ : centroid of the coordinated $\mathrm{Cp}^{\prime}$ moiety (C2 to $\mathrm{C} 6$ ). [b] $C_{\mathrm{g}, \text { allyl }}$ : centroid of the coordinated $\eta^{3}$-allyl moiety (C9 to C11).

The carboxylic acid group drives the crystal packing in $\mathbf{1}$ through the formation of the $\mathbf{R}_{2}^{2}(8)$ graph set motif typical of this functional group (see Figure 3 and Table 2 for geometrical details). ${ }^{[35]}$ The resulting centrosymmetric supramolecular dimer is the effective molecular unit that close packs in the solid state to yield the crystal structure of $\mathbf{1}$. The crystal packing is mostly driven by the need to effectively fill the available space using this supramolecular dimer, as shown in Figure 4. Indeed, besides the aforementioned graph set motif, only a weak $\mathrm{C}-\mathrm{H} \cdots \mathrm{O}$ hydrogen bond connecting adjacent dimers exists in the crystal structure.

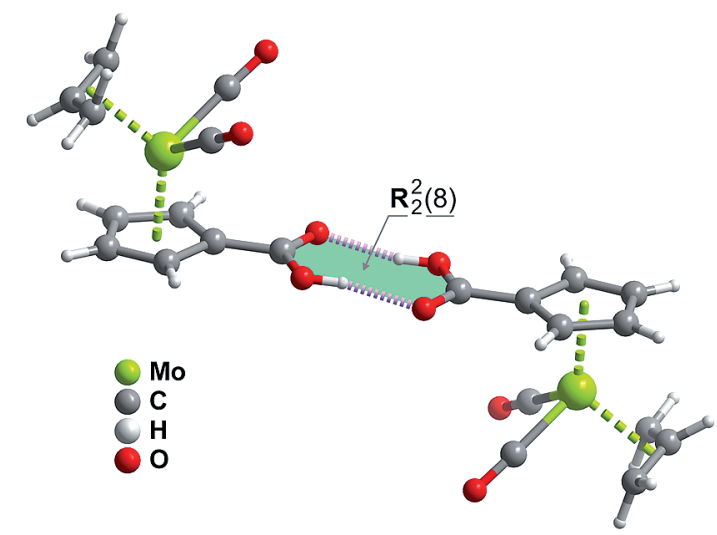

Figure 3. Schematic representation of the centrosymmetric supramolecular dimer of $\left[\left(\eta^{5}-\mathrm{C}_{5} \mathrm{H}_{4}-\mathrm{COOH}\right) \mathrm{Mo}(\mathrm{CO})_{2}\left(\eta^{3}-\mathrm{C}_{3} \mathrm{H}_{5}\right)\right]$ complexes formed by a $\mathbf{R}_{2}^{2}(8)$ graph set motif. ${ }^{[35]} \mathrm{Mo}-\mathrm{C}$ bonds to the $\mathrm{Cp}^{\prime}$ and $\eta^{3}$-allyl organic ligands are replaced by green dashed bonds to the corresponding centroids $\left(C_{\mathrm{g}, \mathrm{Cp}}\right.$ and $\left.C_{\mathrm{g}, \text { allyl }}\right)$. For geometrical details on these contacts, see Table 2.

Table 2. Supramolecular contacts found in the crystal structure of 1. Distances are given in $\AA$ and interaction angles in degrees. ${ }^{[a]}$

\begin{tabular}{lcc}
\hline $\mathrm{D}-\mathrm{H} \cdots \mathrm{A}$ & $d(\mathrm{D} \cdots \mathrm{A})$ & $<(\mathrm{DHA})$ \\
\hline $\mathrm{O} 1-\mathrm{H} 1 \mathrm{~A} \cdots \mathrm{O} 2^{\mathrm{i}}$ & $2.637(3)$ & 168 \\
$\mathrm{C} 3-\mathrm{H} 3 \cdots \mathrm{O} 3^{\mathrm{ii}}$ & $3.182(3)$ & 123
\end{tabular}

[a] Symmetry transformations used to generate equivalent atoms: (i) $1-x, 1-y,-z$; (ii) $1-x, 1 / 2+y, 1 / 2-z$. 
(a)

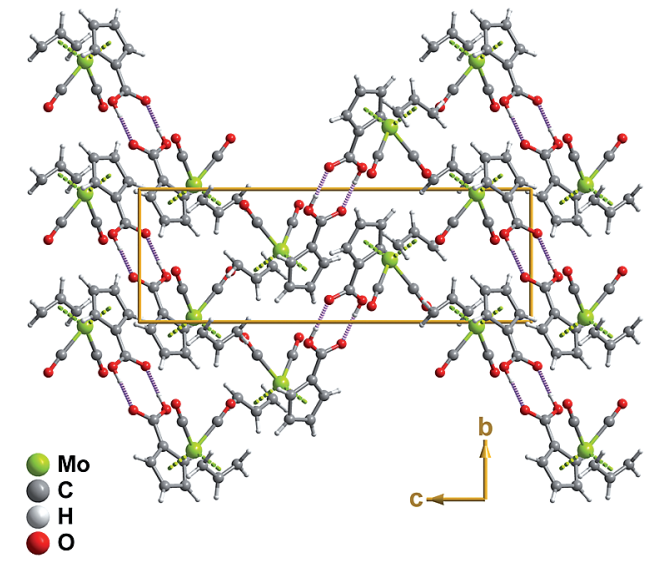

(b)
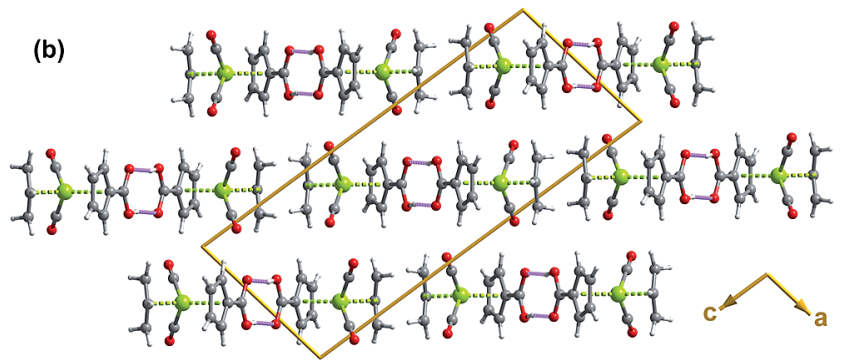

Figure 4. Crystal packing of $\left[\left(\eta^{5}-\mathrm{C}_{5} \mathrm{H}_{4}-\mathrm{COOH}\right) \mathrm{Mo}(\mathrm{CO})_{2}\right.$ $\left(\eta^{3}-\mathrm{C}_{3} \mathrm{H}_{5}\right)$ ] (1) viewed along the (a) [100] and (b) [010] directions of the unit cell. Mo-C bonds to the $\mathrm{Cp}^{\prime}$ and $\eta^{3}$-allyl organic ligands have been replaced by green dashed bonds to the corresponding centroids $\left(C_{\mathrm{g}, \mathrm{Cp}}\right.$ and $\left.C_{\mathrm{g}, \text { allyl }}\right)$.

\section{Inclusion Compounds}

The relative solubilities of $\beta-C D$, TRIMEB and complexes $\mathbf{1}$ and $\mathbf{2}$ determined the method used for the preparation of the respective inclusion compounds. For the carboxylic acid derivative 1, a solution of the complex in dichloromethane was mixed with an aqueous solution of $\beta-C D$. Upon stirring at $40{ }^{\circ} \mathrm{C}$, a pale yellow precipitate formed at the interface between the two solutions, which was recovered by filtration, washed with water and dried to give the product designated as $\beta-\mathrm{CD} \cdot \mathbf{1}$. Although an initial $\mathrm{CD} /$ guest molar ratio of 1:1 was used, elemental analysis for $\mathrm{C}$ and Mo was more consistent with a final CD/guest molar ratio of 2:1 [as also supported by thermogravimetric analysis (TGA), described below]. For the preparation of $\beta$ $\mathrm{CD} \cdot \mathbf{2}$, a solution of $\mathbf{2}$ in ethanol was added to an aqueous solution of $\beta-C D$ (in a 1:2 molar ratio), and the solvents were subsequently removed by freeze-drying. As carried out previously for related TRIMEB/organometallic inclusion compounds, ${ }^{[20 a, 21,23]}$ inclusion of complexes $\mathbf{1}$ and $\mathbf{2}$ in the methylated cyclodextrin was performed by codissolution of the host and guest (in 2:1 and 1:1 molar ratios, respectively) in dichloromethane followed by removal of the solvent under reduced pressure to give the solids designated as TRIMEB· 1 and TRIMEB·2.

TGA traces of compounds $\beta$-CD $\mathbf{1}$, TRIMEB·1, $\beta$-CD·2 and TRIMEB. 2 are given in Figures 5 and 6 , and are compared with those obtained for physical mixtures obtained by cogrinding the host and guest in adequate molar ratios (either $1: 1$ or $2: 1$ ) for a few seconds. The $2: 1 \beta-C D /(1$ or 2) physical mixtures exhibit comparable thermal behaviour characterised by two well-defined steps up to $250^{\circ} \mathrm{C}$ that can be attributed to the loss of water up to about $100^{\circ} \mathrm{C}$ and the loss of the $\mathrm{CO}$ ligands from the organometallic complex (1 or 2) between 170 and $190^{\circ} \mathrm{C}$ (Figure 5). Decomposition of $\beta-\mathrm{CD}$ and the remaining organic ligands of the organometallic complexes overlaps and takes place between 250 and $500{ }^{\circ} \mathrm{C}$ for both physical mixtures. Hence, as expected, each component in the physical mixtures be-

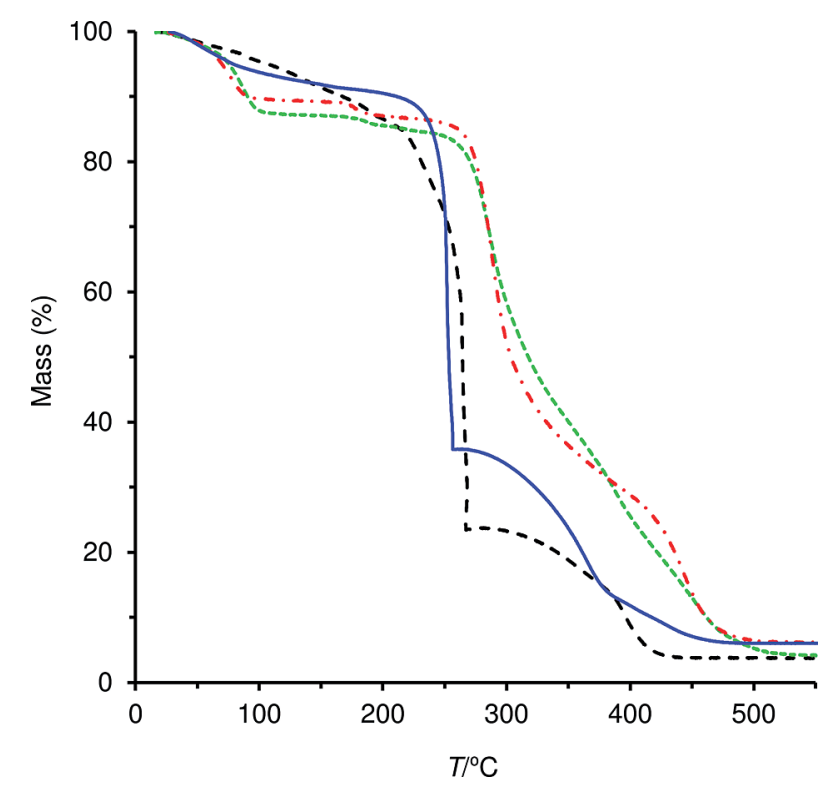

Figure 5. TGA curves for the inclusion compounds $\beta-\mathrm{CD} \cdot \mathbf{1}(---)$ and $\beta-C D \cdot 2(-)$, and the $2: 1$ (host/guest) physical mixtures of $\beta$ $\mathrm{CD}$ with either $\mathbf{1}(----)$ or $\mathbf{2}(-\cdot-\cdot)$.

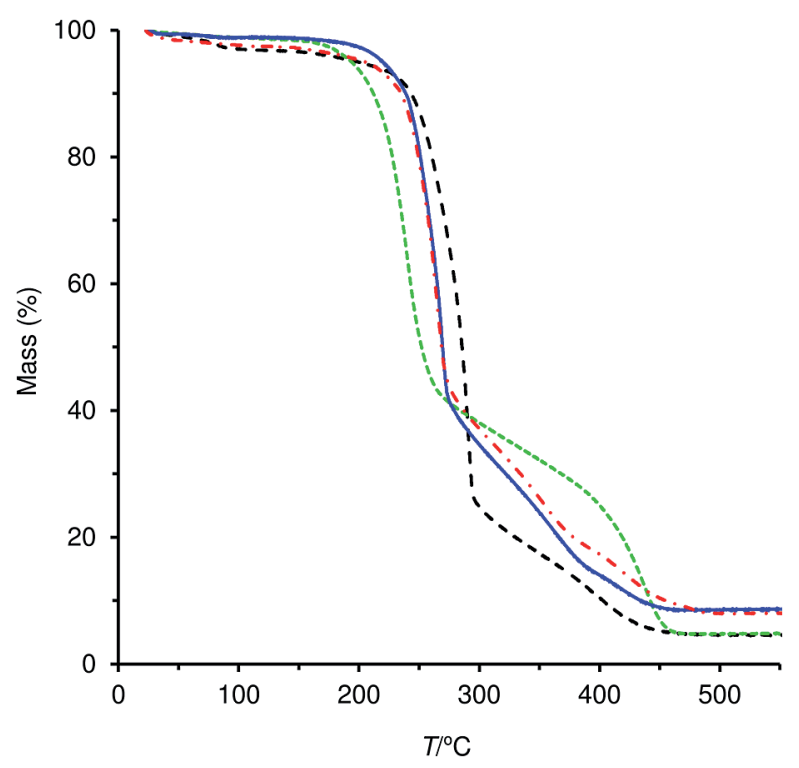

Figure 6. TGA curves for the inclusion compounds TRIMEB·1 $(--)$ and TRIMEB·2 (-), the 2:1 (host/guest) physical mixture of TRIMEB with 1 (-----), and the 1:1 physical mixture of TRIMEB with $2(-\cdot-\cdot)$. 
haves independently upon heating, showing weight-loss steps that coincide with those of the pure compounds (not shown here). By contrast, the TGA traces for the inclusion compounds are quite distinct from those for the physical mixtures. An abrupt dehydration step is no longer observed and instead loss of water extends from room temperature up to the point (ca. $220^{\circ} \mathrm{C}$ ) at which the host macrocycle begins to decompose. While no individual step for CO loss is evident for $\beta$-CD $\mathbf{2}, \beta-C D \cdot 1$ exhibits a noticeable $1.9 \%$ mass-loss step between 180 and $195^{\circ} \mathrm{C}$, which is in good agreement with the theoretical value of $1.8 \%$ calculated (for the loss of two $\mathrm{CO}$ molecules) on the basis of the proposed formula $2\left(\mathrm{C}_{42} \mathrm{H}_{70} \mathrm{O}_{35}\right) \cdot\left(\mathrm{C}_{11} \mathrm{H}_{10} \mathrm{MoO}_{4}\right) \cdot 27 \mathrm{H}_{2} \mathrm{O}$. For both $\beta$ $\mathrm{CD} \cdot \mathbf{1}$ and $\beta-\mathrm{CD} \cdot \mathbf{2}$, the onset of $\beta-\mathrm{CD}$ degradation is shifted to lower temperature by about $40{ }^{\circ} \mathrm{C}$ when compared with that observed in the physical mixtures. This difference may be due to the promoting effect of molybdenum on the decomposition of $\beta-\mathrm{CD}$ and to the different crystal packing for $\beta-C D \cdot 1$ or the amorphous condition $\beta-C D \cdot 2$ (details on the powder XRD of these solids are given in the following paragraphs). The residual masses at $550{ }^{\circ} \mathrm{C}$ of $4.1 \%$ for $\beta$ $\mathrm{CD} \cdot \mathbf{1}$ and $6.0 \%$ for $\beta-\mathrm{CD} \cdot \mathbf{2}$ match those observed for the 2:1 physical mixtures. Overall, the TGA traces of the $\beta$-CD adducts with 1 and 2 are typical of true inclusion compounds of $\beta$-CD with organometallic molecules, ${ }^{[10,21,23]}$ and support the existence of strong host-guest interactions.

TGA of the TRIMEB adducts with $\mathbf{1}$ and $\mathbf{2}$ showed minor mass losses of 3.3 and $1.3 \%$, respectively, from room temperature to $150^{\circ} \mathrm{C}$, attributed to the removal of water. Pure TRIMEB starts to melt and decompose at $170{ }^{\circ} \mathrm{C}^{[36]}$ and a similar behaviour is exhibited by the $2: 1$ physical mixture of TRIMEB and $\mathbf{1}$ (Figure 6). Interestingly, in TRIMEB 1 the host decomposition begins at a temperature roughly $35^{\circ} \mathrm{C}$ higher, thereby showing an opposite trend to that exhibited by $\beta-C D \cdot 1$. This behaviour, although rather unusual, mimics that seen previously upon inclusion of $\mathrm{Cp}_{2} \mathrm{MoCl}_{2},{ }^{[36]} \mathrm{Cp}_{2} \mathrm{NbCl}_{2}{ }^{[37]}$ and $\left[\mathrm{CpMo}(\mathrm{CO})_{3} \mathrm{CH}_{2^{-}}\right.$ $\left.\mathrm{CONH}_{2}\right]^{[21]}$ into TRIMEB. The higher stability of the inclusion compound may be related to the changes in the conformation of the host molecules or in their solid-state packing. In turn, the TGA traces for TRIMEB- 2 and the corresponding 1:1 physical mixture are remarkably similar, with the onset of host decomposition being at approximately $225^{\circ} \mathrm{C}$. Grinding of 2 and TRIMEB together followed by mild heating (up to $170^{\circ} \mathrm{C}$ ) may be sufficient to induce an interaction and even inclusion compound formation between the two components, with the result that the thermal behaviour towards higher temperatures is comparable with that of the adduct TRIMEB-2. Similar results were reported previously for $\mathrm{Cp}_{2} \mathrm{MoCl}_{2}$ and TRIMEB, ${ }^{[36]}$ and for [Eu\{1-(2-naphthoyl)-3,3,3-trifluoroacetonate $\left.\}_{3}\left(\mathrm{H}_{2} \mathrm{O}\right)_{2}\right]$ and octakis(2,3,6-tri- $O$-methyl)- $\gamma$-CD (TRIMEG). ${ }^{[38]}$ For complex 1, the same effect would most likely not be possible due to the presence of strongly hydrogen-bonded dimers in its crystal lattice. As observed for the $\beta$-CD systems, the residual masses at $550{ }^{\circ} \mathrm{C}$ of $4.5 \%$ for TRIMEB 1 and $8.7 \%$ for TRIMEB·2 match those observed for the physical mixtures.
Powder X-ray diffraction (XRD) gives useful information about the formation or otherwise of genuine inclusion compounds of cyclodextrins. When no inclusion complexation occurs upon reacting host and guest, the experimental PXRD trace should be just a combination of the patterns of the separate solid phases. ${ }^{[39]}$ Compounds $\beta$ CD 2 and TRIMEB 2 displayed only a few very broad and weak reflections (not shown), which indicated very low crystallinity, even though these adducts were prepared from microcrystalline materials (complex 2, $\beta$-CD hydrate and TRIMEB, showing numerous relatively intense and sharp reflections in the $2 \theta$ range of $\left.3-30^{\circ}\right)$. The absence of reflections in the powder XRD patterns of $\beta-C D \cdot 2$ and TRIMEB $\mathbf{2}$ due to non-included $\mathbf{2}$ and/or pure CD shows that no recrystallisation of $\mathbf{2}$ or $\beta$-CD/TRIMEB occurred, thus suggesting that these are pure and stable inclusion compounds. For $\beta$-CD 1 and TRIMEB·1, the formation of true inclusion compounds was strongly supported by powder XRD due to the appearance of several new reflections, which indicated the formation of a new crystalline phase, and the absence of peaks characteristic of non-included $\mathbf{1}$ and/or pure CD (Figure 7).

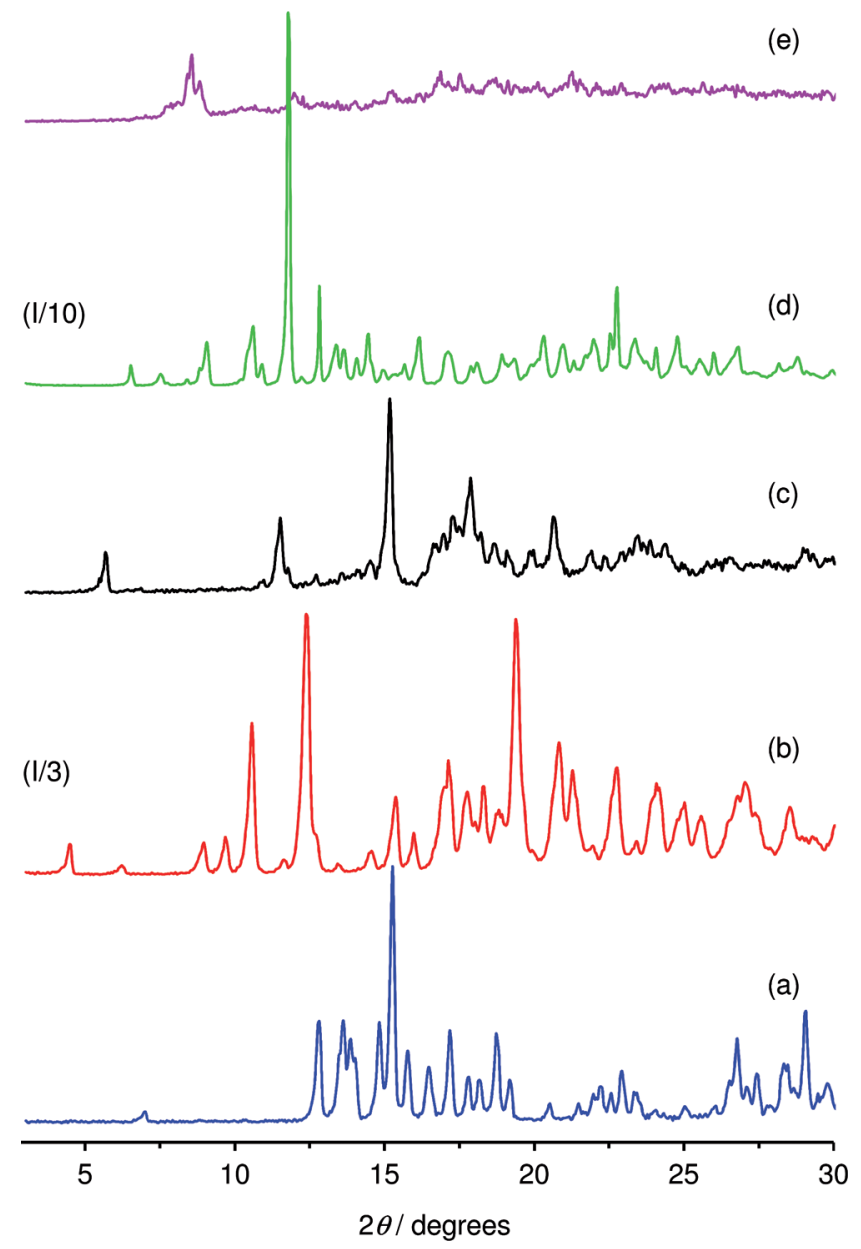

Figure 7. Powder XRD patterns of (a) complex 1, (b) $\beta$-CD, (c) $\beta$ CD $\mathbf{1}$, (d) TRIMEB and (e) TRIMEB $\mathbf{1}$.

The inclusion compounds were further characterised by FTIR spectroscopy and ${ }^{13} \mathrm{C}\left\{{ }^{1} \mathrm{H}\right\}$ CP MAS NMR spec- 
troscopy. The FTIR spectra of the inclusion compounds are dominated by the intense and characteristic absorption bands of the host cyclodextrins. In addition, several guest bands are observed. In the CO (carbonyl ligand) stretching region (1850-2000 $\left.\mathrm{cm}^{-1}\right), \beta-C D \cdot 1$ exhibits three bands with medium intensity at 1880,1929 and $1955 \mathrm{~cm}^{-1}$, similar to those observed for $\mathbf{1}$ (in $\mathrm{KBr}$ ). Three bands are also observed for TRIMEB 1 at 1889,1910 and $1963 \mathrm{~cm}^{-1}$. The spectrum of $\beta-C D \cdot 1$ contains additional guest-centred bands at 820 (out-of-plane $\mathrm{CH}$ deformation of the $\mathrm{Cp}$ ring), 1479 (C-C stretching vibration of the $\mathrm{Cp}$ ring), and $1679 \mathrm{~cm}^{-1}$ (carbonyl stretching vibration of the $\mathrm{COOH}$ ), which are all unshifted when compared with the corresponding bands for $\mathbf{1}$. By contrast, the former two bands were not clearly observed for TRIMEB 1 , and the $v_{\mathrm{CO}}$ of the $\mathrm{COOH}$ was blueshifted to $1723 \mathrm{~cm}^{-1}$, thus indicating that in TRIMEB·1 the carboxylic acid group is not involved in any significant hydrogen-bonding interaction(s). It can thus be postulated that the inclusion geometry of $\mathbf{1}$ in TRIMEB involves isolation of the $\mathrm{COOH}$ fragment resulting from its insertion deep inside the cavity along with partial encapsulation of the $\mathrm{Cp}$ group. Indeed, although TRIMEB is overall much more hydrophobic than $\beta-\mathrm{CD}$, computational studies have shown that these two cyclodextrins have opposite lipophilicity profiles. TRIMEB has a pronounced hydrophilic central cavity and strong hydrophobicity at the torus rims, since these are densely covered in methyl groups; in turn, $\beta-C D$ features a hydrophobic cavity while the wider torus rim carrying the secondary hydroxy groups is distinctly hydrophilic. ${ }^{[40]}$ These differences in the lipophilicity profiles of the hosts are likely to be important driving forces behind different inclusion modes for the guest complex $\left[\left(\eta^{5}-\mathrm{C}_{5} \mathrm{H}_{4}-\mathrm{COOH}\right) \mathrm{Mo}(\mathrm{CO})_{2}\left(\eta^{3}-\mathrm{C}_{3} \mathrm{H}_{5}\right)\right]$ (1): it may be encapsulated in TRIMEB by means of insertion of the hydrophilic, polar $\mathrm{COOH}$ group into its cavity, whereas in $\beta$ $\mathrm{CD} \cdot 1$ the geometry may be different so as to permit hydrogen-bonding interactions of the $\mathrm{COOH}$ group with adjacent water molecules and/or host $\mathrm{OH}$ groups (Figure 8).

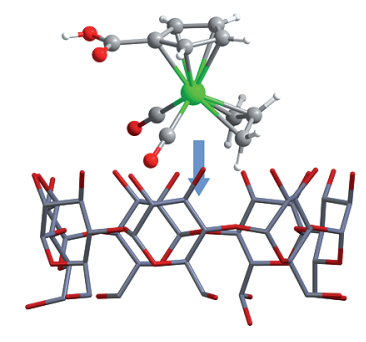

$\beta-\mathrm{CD} \cdot 1$

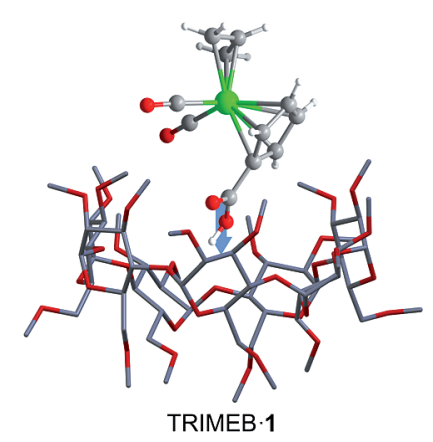

TRIMEB·1
Figure 8 . Schematic representation of the possible inclusion modes for $\beta$-CD·1 and TRIMEB·1.

The FTIR spectrum of 2 (in $\mathrm{KBr}$ ) contains three strong terminal carbonyl absorptions at 1867,1944 and $1965 \mathrm{~cm}^{-1}$, $v_{\mathrm{CO}}$ at $1741 \mathrm{~cm}^{-1}$ for the ester group, and three bands for the CONH group at 1534 (amide II band, mainly $\mathrm{N}-\mathrm{H}$ bending), 1622 (amide I band, mainly $\mathrm{C}=\mathrm{O}$ stretching) and $3304 \mathrm{~cm}^{-1}\left(v_{\mathrm{NH}}\right)$. Both $\beta$-CD 2 and TRIMEB·2 exhibit two terminal carbonyl absorptions at approximately 1870 and $1950 \mathrm{~cm}^{-1}$. The $v_{\mathrm{CO}}$ band for the ester group is present as an isolated absorption at $1747 \mathrm{~cm}^{-1}$ for TRIMEB 2 and as a shoulder at $1733 \mathrm{~cm}^{-1}$ for $\beta-C D \cdot 2$. The inclusion compound TRIMEB 2 exhibits three other guest-centred bands at 1539 (amide II), 1660 (amide I) and $3307 \mathrm{~cm}^{-1}\left(v_{\mathrm{NH}}\right)$ that can be attributed to the amide group. In the spectrum of $\beta$-CD.2 the $v_{\mathrm{NH}}$ bands are obscured owing to the higher host/guest stoichiometry (2:1), overlap of the $v_{\mathrm{NH}}$ vibration with the very strong and broad $v_{\mathrm{OH}}$ band centred at approximately $3370 \mathrm{~cm}^{-1}$, and overlap of the amide I/II bands with a water bending vibration at $1645 \mathrm{~cm}^{-1}$ and host vibrations below $1550 \mathrm{~cm}^{-1}$. The shift of the amide I band from $1622 \mathrm{~cm}^{-1}$ for 2 to $1660 \mathrm{~cm}^{-1}$ for TRIMEB·2 is noteworthy. In the crystal structure of $\mathbf{2},{ }^{[17]}$ hydrogen-bonding interactions are present between amide groups of neighbouring molecules. Hence, in an analogous fashion to that observed for the $\mathrm{COOH}$ groups in $\mathbf{1}$, the shift of the amide I band may indicate that TRIMEB inclusion is accompanied by the loss of the intermolecular hydrogen bonds involving the amide groups of $\left[\left(\eta^{5}-\mathrm{C}_{5} \mathrm{H}_{4}-\mathrm{CO}-\mathrm{Phe}-\mathrm{OMe}\right) \mathrm{Mo}(\mathrm{CO})_{2}\left(\eta^{3}-\mathrm{C}_{3} \mathrm{H}_{5}\right)\right]$

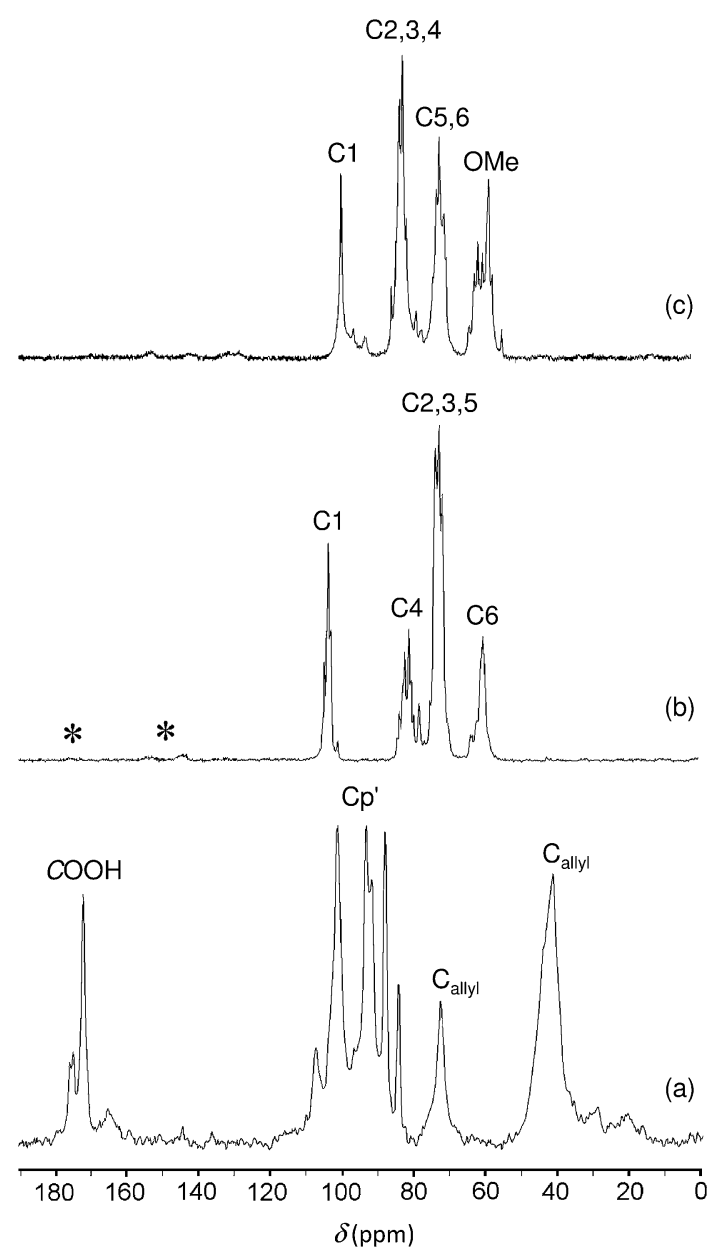

Figure 9. ${ }^{13} \mathrm{C}\left\{{ }^{1} \mathrm{H}\right\}$ CP MAS NMR spectra of (a) complex 1, (b) $\beta-C D \cdot 1$ and (c) TRIMEB 1 . Spinning sidebands are denoted by asterisks. 
molecules. Accordingly, concerning the terminal carbonyl absorptions and the amide I band, the spectrum of $\mathbf{2}$ in $\mathrm{CH}_{2} \mathrm{Cl}_{2}$ (bands at 1664,1869 and $\left.1950 \mathrm{~cm}^{-1}\right)^{[17]}$ strongly resembles that of TRIMEB·2.

The solid-state ${ }^{13} \mathrm{C}\left\{{ }^{1} \mathrm{H}\right\}$ CP MAS NMR spectra of complex 1, $\beta$-CD.1 and TRIMEB·1 are shown in Figure 9. The spectra collected for the inclusion compounds are dominated by the resonances arising from the host macrocycles. Indeed, due in part to the final host/guest molar ratio being $2: 1$, the resonances of the organometallic guest cannot be clearly discerned. The different carbon resonances of $\beta-C D$ in $\beta$-CD 1 are assigned to $\mathrm{C} 1$ (101-105 ppm), C4 (77$84 \mathrm{ppm}), \mathrm{C} 2,3,5$ (70-75 ppm) and C6 (60-64 ppm). A practically identical spectrum was obtained previously for the 2:1 (host/guest) inclusion compound comprising $\beta-C D$ and the tetrafluoroborate salt $\left[\mathrm{CpMo}\left(\eta^{4}-\mathrm{C}_{6} \mathrm{H}_{8}\right)(\mathrm{CO})_{2}\right] \mathrm{BF}_{4} \cdot{ }^{[20 \mathrm{~b}]}$ In the spectrum of pure $\beta$-CD hydrate (not shown), the chemical shifts of the C-1 and C-4 resonances have been correlated with the conformation about the $(1 \rightarrow 4)$ linkage and those of the C-6 resonances are sensitive to the dynamics of the hydrogen-bonding interactions. ${ }^{[1]}$ The spectrum of TRIMEB· 1 also shows multiple resonances for the host
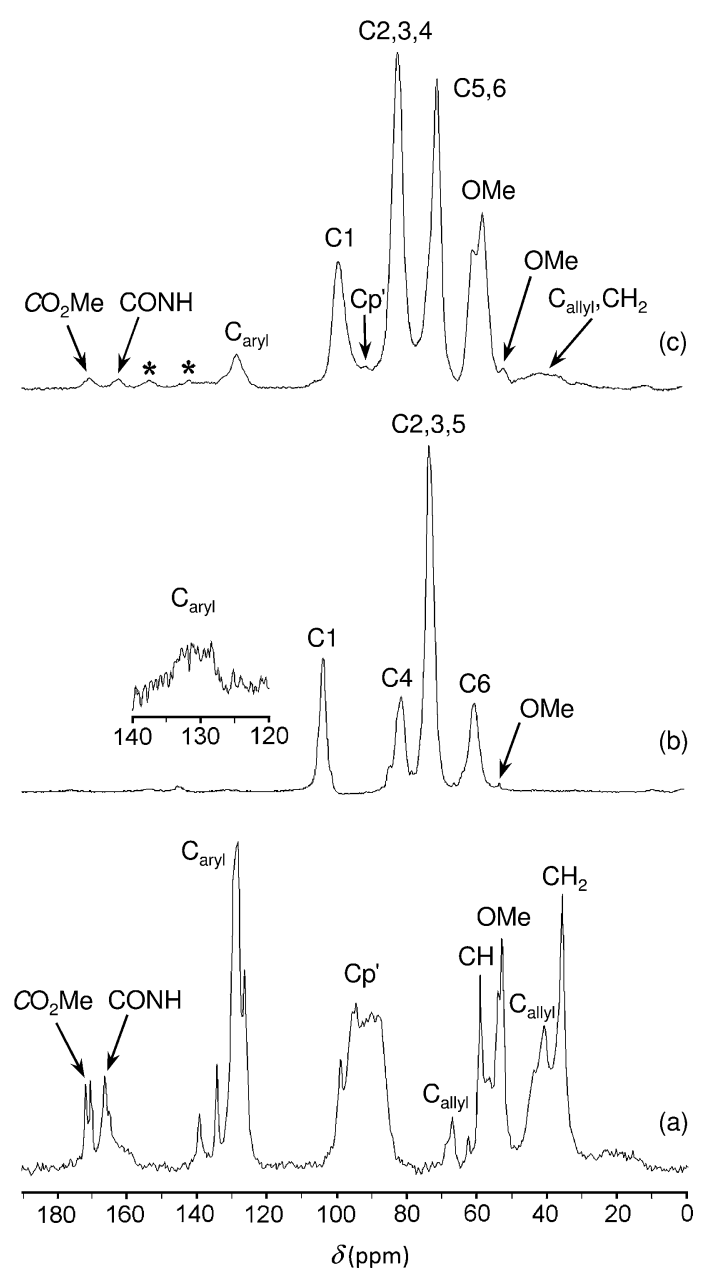

Figure 10. ${ }^{13} \mathrm{C}\left\{{ }^{1} \mathrm{H}\right\}$ CP MAS NMR spectra of (a) complex 2, (b) $\beta-C D \cdot 2$ and (c) TRIMEB·2. Spinning sidebands are denoted by asterisks. carbon atoms, which are remarkably similar to those reported for several other TRIMEB inclusion compounds with organometallic guests. ${ }^{[21,23,37]}$ The presence of several resolved lines is consistent with an ordered crystal-packing arrangement of the TRIMEB molecules. Indeed, at least eight resonances are discernible for the methyl carbon atoms, which indicates that these groups exist in several different well-defined environments. A comparison of the spectra obtained for $\beta$-CD·1 and TRIMEB· 1 with those of the pure hosts reveals considerable differences in the number, relative intensities and positions of peaks, which indicates that inclusion has induced changes in the conformation of the macrocycles.

In the ${ }^{13} \mathrm{C}\left\{{ }^{1} \mathrm{H}\right\}$ CP MAS NMR spectra of $\beta-C D \cdot 2$ and TRIMEB·2, the signals for the cyclodextrin carbon atoms appear mainly as single broad peaks (Figure 10). Since powder XRD showed that the samples are amorphous, structural disorder in the solid state is likely to be the main cause of the broadening of the host carbon resonances. Very weak signals for the aryl and methoxy carbon atoms of the guest are present in the spectrum of $\beta-C D \cdot 2$. These signals are much more evident in the spectrum of TRIMEB·2 (as expected, owing to the host/guest molar ratio of 1:1), and additional signals due to the COOMe, $\mathrm{CONH}, \mathrm{Cp}^{\prime}$, allyl and $\mathrm{CH}_{2}$ carbon atoms of the guest molecule are observed.

\section{Antiproliferative Activity}

The antiproliferative action of $\eta^{3}$-allyl(dicarbonyl)molybdenum complexes was recently demonstrated. For a family of $\left[\mathrm{Mo}\left(\eta^{3}-\mathrm{C}_{3} \mathrm{H}_{3}\right) \mathrm{X}(\mathrm{CO})_{2}(\mathrm{~L})\right]$ complexes $[\mathrm{X}=\mathrm{Br}$, $\mathrm{CF}_{3} \mathrm{SO}_{3} ; \quad \mathrm{L}=2,2^{\prime}$-bisimidazole, 2-(2'-pyridyl)benzimidazole, 2-(2'-pyridyl)imidazole], tested as cytotoxic agents against the in vitro growth of $\mathrm{HeLa}$ cells, $\mathrm{IC}_{50}$ values were reported in the 12 to $118 \mu \mathrm{M}$ range [3-(4,5-dimethylthiazol2-yl)-2,5-diphenyltetrazolium bromide (MTT) assay with an incubation time of $48 \mathrm{~h}] .{ }^{[18 a]}$ Later on, Bandarra et al. prepared new complexes of this family with $\mathrm{X}=\mathrm{Cl}, \mathrm{Br}$, $\mathrm{CF}_{3} \mathrm{SO}_{3}$ and $\mathrm{L}=2,2^{\prime}$-bipyridine or 1,10-phenanthroline, and tested these against the human cancer cell lines HeLa, MCF7 and N1E-115, with $\mathrm{IC}_{50}$ values being found in the 3 to $60 \mu \mathrm{M}$ range (also using the MTT assay and $48 \mathrm{~h}$ of incubation). ${ }^{[18 \mathrm{~b}]}$ It was thus found useful to study the growth-inhibition properties of the compounds described in this work against tumour cell lines. For this, we used the colorimetric sulforhodamine B (SRB) assay, which affords comparable results for chemosensitivity of tumour cell lines in end-point determinations but is known to have higher sensitivity and better linearity with the cell number than the MTT assay, and is thus recommended for growth kinetics studies (cell proliferation over time, with or without drugs). ${ }^{[42]}$

Compounds 1, 2, $\beta$-CD $\mathbf{1}$, TRIMEB $\mathbf{1}, \beta-\mathrm{CD} \cdot \mathbf{2}$ and TRIMEB $\mathbf{2}$ were tested against two distinct tumour cell lines of different origins: (i) melanoma cells from mouse (K1735-M2), a model for highly invasive metastatic melanoma, previously used to investigate the chemotherapeutic 
potential of several molecules; ${ }^{[43,44]}$ and (ii) human adenocarcinoma (MDA-MB-231), an estrogen receptor negative epithelial cell line extracted from the mammary gland, regarded as one of the most important models for breast cancer cells. ${ }^{[45]}$ To evaluate the antitumour selectivity of the compounds under study, a nontumorigenic cell line, the rat myoblast cells (H9c2), was chosen based on its extensive use to investigate the muscle toxicity of both novel and clinically used chemotherapeutics. ${ }^{[46]}$ A range of compound concentrations from 1 to $100 \mu \mathrm{M}$ was tested and cell mass was measured at different time points for up to four days of incubation. Figure 11 shows the cell-density values before and after treatment, measured by the SRB assay.
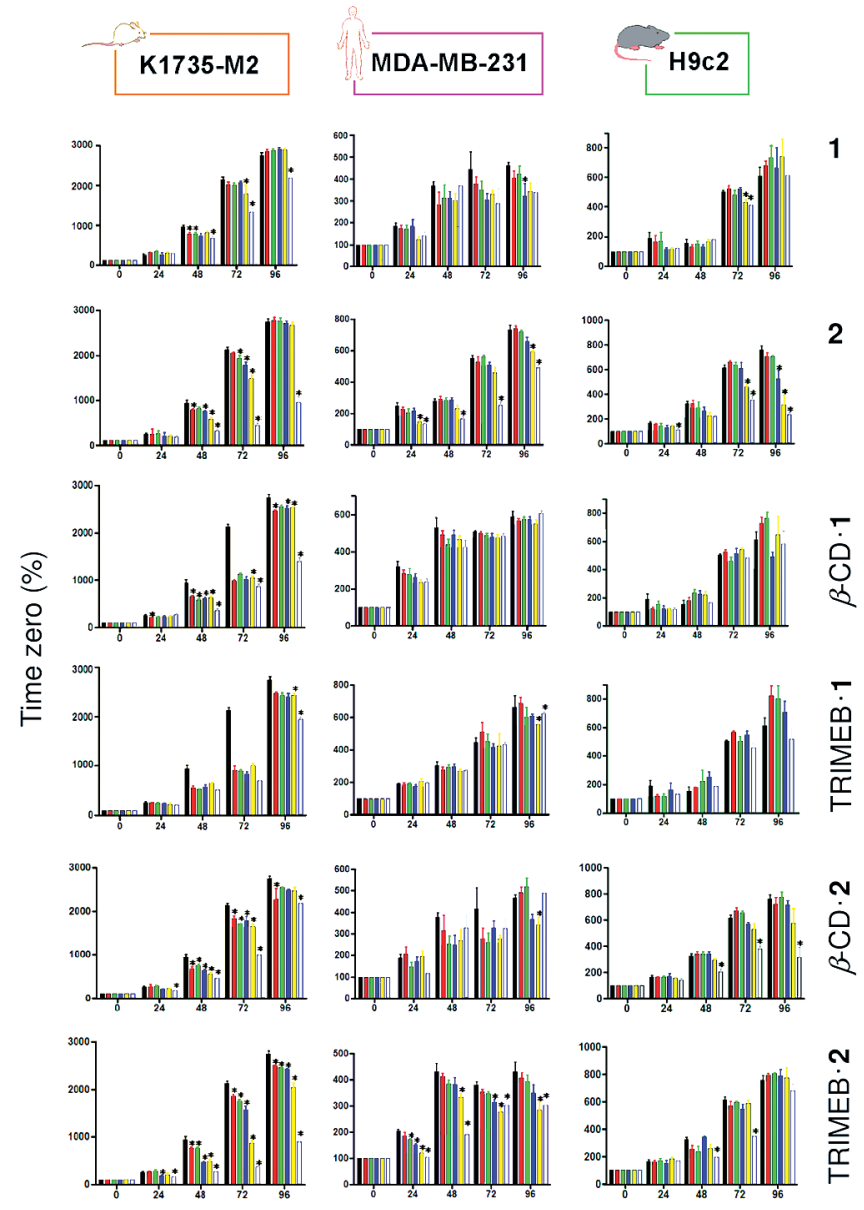

Incubation time (h)
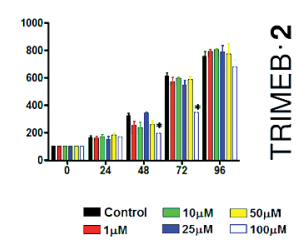

Figure 11. Evaluation of the effects of compounds 1, 2, $\beta$-CD·1, TRIMEB $1, \beta-C D \cdot 2$ and TRIMEB 2 on the K1735-M2, MDAMB-231 and H9c2 cell line mass (expressed as a percentage of the mass at time zero); cell mass is a direct measurement of cell proliferation. Data were obtained by using the SRB assay as described in the Experimental Section. Each cell line shows different rates of proliferation with time under untreated conditions. Data are means \pm SEM (standard error of the mean) of at least four independent experiments. The asterisk $\left.{ }^{*}\right)$ indicates $p<0.05$ versus control for the same time point.

The pure complexes $\mathbf{1}$ and $\mathbf{2}$ led to different results, with carboxylic acid derivative $\mathbf{1}$ being less toxic than phenylalanine $\mathbf{2}$. The overall cytotoxicity of complex $\mathbf{1}$ on tumour cell lines was clearly more evident for the mouse melanoma cell line than for the human breast cancer line. Interestingly, cytotoxicity on the melanoma cell line decreased with longer incubation times, which suggests cell recovery. Encapsulation of $\mathbf{1}$ into cyclodextrins yields some interesting results, as $\beta$-CD·1 and TRIMEB·1 show distinct effects regarding the antiproliferative activity. The activity of TRIMEB 1 against the breast cancer cell line was minimal and only visible at the highest concentration tested and for the longest incubation time. Against the melanoma cell line, the antiproliferative action of $\beta-C D \cdot 1$ increased, whereas for TRIMEB·1 growth inhibition was observed but without statistical significance. In contrast, the inclusion compounds $\beta-C D \cdot 1$ and TRIMEB· 1 exhibited no significant toxicity against the nontumour line, as also observed for pure 1 (with the exception of the highest concentration at the $3 \mathrm{~d}$ time point). There was also no antiproliferative activity against $\mathrm{H} 9 \mathrm{c} 2$ cells.

Complex 2 was more active with respect to inhibition of the cell proliferation than its precursor $\mathbf{1}$, especially for the breast cancer and nontumour cell line. It should be noted that the incorporation of the phenylalanine moiety did not afford selectivity towards the tumour cell lines. Indeed, complex 2 equally affected all the cell lines tested in the present work, especially for the highest concentrations used. Fairly similar results were obtained for the cyclodextrin inclusion compounds, with some notable variations. Adduct $\beta-C D \cdot 2$ exhibited increased toxicity for K1735-M2, although some proliferation recovery appears to take place after $96 \mathrm{~h}$ of exposure time. Note also that adduct $\beta-C D \cdot 2$ is not toxic against the human breast cancer cell line, and presents only moderate toxicity for the myoblast cell line at the highest concentrations tested. TRIMEB encapsulation yields a predominant growth-inhibition effect on tumour cells versus the non-neoplastic myoblast cell line. Against the K1735-M2 melanoma cell line, TRIMEB·2, was toxic for almost all concentrations and time points tested. For the breast cancer cell line, similar results were obtained, although some cell recovery seems to occur with time. TRIMEB 2 only displayed antiproliferative activity against the non-tumour myoblast cell line for the highest concentration tested $(100 \mu \mathrm{M})$ and after three days of treatment.

\section{Conclusion}

In this work, the preparation of cyclodextrin ( $\beta-C D$ and TRIMEB) inclusion compounds with the organometallic guests $\left[\left(\eta^{5}-\mathrm{C}_{5} \mathrm{H}_{4}-\mathrm{COOH}\right) \mathrm{Mo}(\mathrm{CO})_{2}\left(\eta^{3}-\mathrm{C}_{3} \mathrm{H}_{5}\right)\right]$ (1) and $\left[\left(\eta^{5}-\mathrm{C}_{5} \mathrm{H}_{4}-\mathrm{CO}-\mathrm{Phe}-\mathrm{OMe}\right) \mathrm{Mo}(\mathrm{CO})_{2}\left(\eta^{3}-\mathrm{C}_{3} \mathrm{H}_{5}\right)\right]$ (2) is described. TRIMEB inclusion was achieved by codissolution in $\mathrm{CH}_{2} \mathrm{Cl}_{2}$ followed by solvent evaporation, whereas inclusion into $\beta-\mathrm{CD}$ was carried out by treatment of its aqueous solutions with either complex 1 dissolved in $\mathrm{CH}_{2} \mathrm{Cl}_{2}$ or complex $\mathbf{2}$ dissolved in ethanol. Characterisation of the resultant solids supported the formation of true inclusion compounds. The growth-inhibition activity studies yielded interesting results that are in line with those obtained in 
some of our previous studies of cyclodextrin inclusion compounds of metal-based antitumoural drug candidates. Overall, the inclusion compounds of $\mathbf{1}$ and $\mathbf{2}$ with both $\beta-\mathrm{CD}$ and TRIMEB presented an intrinsic selectivity of action, that is, there was antiproliferative action against tumour cell lines and insignificant inhibition of the growth of the healthy cell line. The same activity profile was recently observed for the $\beta$-CD and TRIMEB inclusion compounds of $\left[\mathrm{Ru}^{\mathrm{II}}\left([9] \mathrm{aneS}_{3}\right)(\right.$ pdon$\left.) \mathrm{Cl}\right] \mathrm{Cl}^{[47]}\left([9] \mathrm{aneS}_{3}=1,4,7\right.$-trithionane; pdon $=1,10$-phenanthroline-5,6-dione) and of $\mathrm{Cp}_{2} \mathrm{MoCl}_{2} \cdot{ }^{[36]}$ The two hosts displayed different antiproliferative activity against the tumour cell lines. The inclusion compound $\beta$-CD.1 presented higher antiproliferative activity against the mouse melanoma K-1735-M2 line than complex $\mathbf{1}$, whereas it showed minimal activity towards the human MDA-MB-231 line; a similar effect was previously observed for $\left[\mathrm{Ru}^{\mathrm{II}}\left([9] \mathrm{aneS}_{3}\right)\right.$ (pdon) $\left.\mathrm{Cl}\right] \mathrm{Cl}$, which upon $\beta-\mathrm{CD}$ inclusion displayed cytotoxicity at $48 \mathrm{~h}$ of incubation against the K-1735-M2 line but not against the human adenocarcinoma lines MDA-MB-231 and MCF-7. ${ }^{[47]}$ The activity of TRIMEB· 1 on both tumour cell lines studied herein was more irregular and did not result in statistically significant values of growth inhibition. Complex $\mathbf{2}$ was a better agent against the growth of tumour cells than 1, but the inclusion into $\beta-\mathrm{CD}$ did not bring any activity improvements. Indeed, the inhibitory action of $\beta-C D \cdot 2$ against the K-1735-M2 line was similar to that of pure 2 and it was insignificant against the human MDA-MB-231 line. In turn, TRIMEB·2 was active against both the mouse and human cancer cell lines, with an overall enhanced action that may be attributed to the solubilising and to the membrane-permeability-facilitating properties of TRIMEB. ${ }^{[48]}$ Overall these preliminary results seem to be sufficiently interesting to motivate further study of the antitumoural properties of this family of organometallic-cyclodextrin inclusion compounds, with one avenue of research being the variation of the substituents on the cyclopentadienyl ligand. Manipulation of the parent molecules may increase their cell-membrane permeability, as well as their activity towards distinct target intracellular sites.

\section{Experimental Section}

Materials and Methods: $\beta-\mathrm{CD}$ (Kleptose, moisture content ca. $15 \%$ ) was kindly donated by Laboratoires La Roquette (France), and TRIMEB was obtained from Fluka. All air-sensitive operations were carried out using standard Schlenk techniques under nitrogen. Solvents were dried by standard procedures, distilled under nitrogen or argon, and kept over $4 \AA$ molecular sieves. Microanalyses for $\mathrm{CHN}$ were performed by $\mathrm{C}$. Almeida at the ITQB, Oeiras, and ICP-OES analyses for Mo were performed by Lina Carvalho at the Central Laboratory for Analysis, University of Aveiro. TGA studies were carried out using a Shimadzu TGA-50 system at a heating rate of $5{ }^{\circ} \mathrm{Cmin}^{-1}$ under air. Powder XRD data were collected on a Philips $\mathrm{X}^{\prime}$ pert MPD diffractometer equipped with an $\mathrm{X}^{\prime}$ Celerator detector and $\mathrm{Cu}-K_{\alpha}$ graphite-monochromated radiation filtered by $\mathrm{Ni}(\lambda=1.5418 \AA$ ) operated with a flat plate holder in a Bragg-Brentano configuration ( $45 \mathrm{kV}$ and $50 \mathrm{~mA}$ ). Intensity data were collected by the step-counting method (step $0.02^{\circ}$ ) in the ca. $3 \leq 2 \theta \leq 50^{\circ}$ range. Infrared spectra were recorded on a Unican Mattson Mod 7000 FTIR spectrophotometer. ${ }^{13} \mathrm{C}\left\{{ }^{1} \mathrm{H}\right\}$ CP MAS NMR spectra were recorded at $125.72 \mathrm{MHz}$ on a $(11.7 \mathrm{~T})$ Bruker Avance 500 spectrometer, with an optimised $\pi / 2$ pulse for ${ }^{1} \mathrm{H}$ of $4.5 \mu \mathrm{s}, 2 \mathrm{~ms}$ contact time, a spinning rate of $7 \mathrm{kHz}$ and $12 \mathrm{~s}$ recycle delays. Chemical shifts are quoted in parts per million from tetramethylsilane.

Synthesis and Characterisation of Guest Complexes: The complexes $\left[\left(\eta^{5}-\mathrm{C}_{5} \mathrm{H}_{4}-\mathrm{CO}-\mathrm{R}\right) \mathrm{Mo}(\mathrm{CO})_{2}\left(\eta^{3}-\mathrm{C}_{3} \mathrm{H}_{5}\right)\right][\mathrm{R}=\mathrm{OH}(\mathbf{1}), \mathrm{Phe}-\mathrm{OMe}(\mathbf{2})]$ were prepared as described previously. ${ }^{[17]}$ Single crystals of $\mathbf{1}$ suitable for X-ray diffraction were obtained after layering a solution of the complex in $\mathrm{CH}_{2} \mathrm{Cl}_{2}$ with diethyl ether/hexane. FTIR ( $\mathrm{KBr}$ ): for 1: $\tilde{v}=3120(\mathrm{~m}), 2965(\mathrm{~m}), 2884(\mathrm{~m}), 2685(\mathrm{~m}), 2633(\mathrm{~m}), 2530$ (m), 2449 (m), 1957 (s, $v_{\mathrm{CO}}$ ), 1921 (vs., $v_{\mathrm{CO}}$ ), 1884 (s, $v_{\mathrm{CO}}$ ), 1862 (s, $\left.v_{\mathrm{CO}}\right), 1679\left(\mathrm{~s}, v_{\mathrm{CO}}\right.$ of $\left.\mathrm{COOH}\right), 1584(\mathrm{~m}), 1480\left(\mathrm{~s}, v_{\mathrm{CC}}, \mathrm{Cp}^{\prime}\right), 1461$ (sh), 1433 (w), 1421 (w), 1406 (m), 1389 (m), 1357 (m), 1310 (m), 1290 (m), 1277 (m), 1170 (m), 1087 (m), 1062 (m), 1048 (m), 1031 (m), $1012(\mathrm{~m}), 952(\mathrm{~m}), 918(\mathrm{~m}), 906(\mathrm{~m}), 890(\mathrm{~m}), 820\left(\mathrm{~m}, \gamma_{\mathrm{CH}}\right.$, Cp'), $778(\mathrm{~m}), 770(\mathrm{~m}), 741(\mathrm{~m}), 610(\mathrm{~m}), 589(\mathrm{~m}), 545(\mathrm{~m}), 532$ (m), 509 (m), 492 (m), 477 (m), 465 (m), $441(\mathrm{~m}), 404(\mathrm{w}), 386(\mathrm{w})$, $378(\mathrm{w}), 353(\mathrm{ww}) \mathrm{cm}^{-1}$; for 2: $\tilde{\mathrm{v}}=3304\left(\mathrm{~m}, \mathrm{v}_{\mathrm{NH}}\right), 3089(\mathrm{~m}), 3032$ (w), 3006 (w), 2954 (m), 2926 (m), 2856 (w), 1965 (vs., $v_{\mathrm{CO}}$ ), 1944 (vs., $v_{\mathrm{CO}}$ ), 1867 (vs., $v_{\mathrm{CO}}$ ), 1741 (vs., $v_{\mathrm{CO}}$ of COOMe), 1622 (s, amide I), 1534 (s, amide II), 1494 (m), 1455 (m), 1445 (m), 1432 (m), 1380 (m), 1348 (m), 1326 (m), 1306 (m), 1274 (w), 1255 (m), 1180 (m), 1101 (w), 1055 (m), 1032 (m), 1017 (m), 995 (m), 931

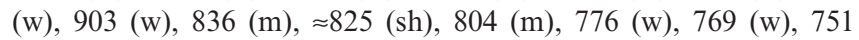
(m), $700(\mathrm{~m}), 662(\mathrm{w}), 631(\mathrm{w}), 619(\mathrm{~m}), 591(\mathrm{~m}), 542(\mathrm{~m}), 500(\mathrm{~m})$, 454 (m), 426 (w), 405 (w), 392 (vw), 382 (w), $365(\mathrm{w}), 354(\mathrm{w}) \mathrm{cm}^{-1}$. ${ }^{13} \mathrm{C}\left\{{ }^{1} \mathrm{H}\right\}$ CP MAS NMR: for 1: $\delta=175.9,175.1,172.1(\mathrm{COOH})$, $107.8\left(C_{\mathrm{Cp}^{\prime}}-\mathrm{CO}\right), 101.6,93.7,92.1,88.4,84.8\left(C_{\mathrm{Cp}^{\prime}}\right), 73.1\left(C_{\text {allyl }}\right)$, $42.1\left(C_{\text {allyl }}\right)$ ppm; for 2: $\delta=239.0,235.8(C O), 171.6,170.4(C O-$ OMe), 166.8, 165.5 (CONH), $139.7\left(C_{\mathrm{Ar}}-\mathrm{CH}_{2}\right), 134.7,129.5,128.6$, $126.8\left(C_{\mathrm{Ar}}\right), 99.5\left(C_{\mathrm{Cp}^{\prime}}-\mathrm{CO}\right), 96.0,95.2,93.2,92.1,90.7,88.5$ $\left(C_{\mathrm{Cp}^{\prime}}\right), 67.4\left(C_{\text {allyl }}\right), 59.8(C \mathrm{H}), 54.8,53.6(\mathrm{OMe}), 44.4,41.7\left(C_{\text {allyl }}\right)$, $36.3\left(\mathrm{CH}_{2}\right) \mathrm{ppm}$.

$\boldsymbol{\beta}-\mathbf{C D} \cdot 1$ : A solution of $\beta$-CD hydrate $(440 \mathrm{mg}, 0.33 \mathrm{mmol})$ in water $(11 \mathrm{~mL})$ at $40^{\circ} \mathrm{C}$ was treated with a solution of the carboxylic acid derivative 1 (100 mg, $0.33 \mathrm{mmol})$ in dichloromethane (12 mL), and the resultant biphasic mixture was stirred for $3 \mathrm{~h}$. During this period, a pale yellow precipitate formed at the interface between the two solutions. The solid was recovered, washed with water $(4 \times 5 \mathrm{~mL})$, and dried. $2\left(\mathrm{C}_{42} \mathrm{H}_{70} \mathrm{O}_{35}\right) \cdot\left(\mathrm{C}_{11} \mathrm{H}_{10} \mathrm{MoO}_{4}\right) \cdot 27 \mathrm{H}_{2} \mathrm{O}$ (3058.5): calcd. C 37.31, H 6.72, Mo 3.13; found C 37.26, H 5.31, Mo 2.33. TGA up to $160{ }^{\circ} \mathrm{C}$ revealed a sample weight loss of $9.4 \%$ (calcd.: for loss of $27 \mathrm{H}_{2} \mathrm{O}, 15.9 \%$; for loss of $15 \mathrm{H}_{2} \mathrm{O}, 9.5 \%$ ). FTIR $(\mathrm{KBr}): \tilde{v}=3364(\mathrm{~s}), 2929(\mathrm{~m}), 2855(\mathrm{~m}), 1955\left(\mathrm{~m}, \mathrm{v}_{\mathrm{CO}}\right), 1929(\mathrm{~m}$, $\left.v_{\mathrm{CO}}\right), 1880\left(\mathrm{~m}, v_{\mathrm{CO}}\right), 1872\left(\mathrm{sh}, v_{\mathrm{CO}}\right), 1865\left(\mathrm{sh}, \mathrm{v}_{\mathrm{CO}}\right), 1679\left(\mathrm{~m}, \mathrm{v}_{\mathrm{CO}}\right.$ of $\mathrm{COOH}), 1645$ (sh), $1479\left(\mathrm{~m}, \mathrm{v}_{\mathrm{CC}}, \mathrm{Cp}^{\prime}\right), 1462(\mathrm{~m}), 1421(\mathrm{~m}), 1407$ (m), $1384(\mathrm{~m}), 1370(\mathrm{~m}), 1335$ (m), 1294 (m), 1247 (m), 1205 (m), 1159 (s), 1103 (m), 1082 (s), 1056 (s), 1030 (vs), 1004 (s), 946 (m), $393(\mathrm{~m}), 861(\mathrm{~m}), 820\left(\mathrm{~m}, \gamma_{\mathrm{CH}}, \mathrm{Cp}^{\prime}\right), 779(\mathrm{~m}), 755(\mathrm{~m}), 742(\mathrm{~m})$, $704(\mathrm{~m}), 663(\mathrm{w}), 611(\mathrm{~m}), 580(\mathrm{~m}), 555(\mathrm{w}), 547(\mathrm{w}), 532(\mathrm{~m}), 508$ (m), $746(\mathrm{~m}), 446$ (w), 437 (w), $425(\mathrm{w}), 415(\mathrm{w}), 406(\mathrm{w}), 386(\mathrm{vw})$, $378(\mathrm{vw}), 360(\mathrm{w}) \mathrm{cm}^{-1} \cdot{ }^{13} \mathrm{C}\left\{{ }^{1} \mathrm{H}\right\}$ CP MAS NMR: $\delta=105.1,104.6$, $103.8,103.5,103.0,(\beta-\mathrm{CD}, \mathrm{C} 1), 100.9\left(\beta-\mathrm{CD}, \mathrm{C} 1\right.$; guest, $\left.C_{\mathrm{Cp}^{\prime}}\right)$, 84.3, 83.7, 82.2, 81.7, 80.5, 79.8, 78.2, 76.8 ( $\beta-\mathrm{CD}, \mathrm{C} 4), 75.1,73.5$, $72.9,72.5,71.9,71.7,70.9,69.9$ ( $\beta-\mathrm{CD}, \mathrm{C} 2,3,5), 64.0,63.5,62.3$, $60.4(\beta-\mathrm{CD}, \mathrm{C} 6) \mathrm{ppm}$.

TRIMEB-1: A solution of TRIMEB (286 mg, $0.2 \mathrm{mmol})$ and carboxylic acid derivative 1 (30 mg, $0.1 \mathrm{mmol})$ in dichloromethane $(8 \mathrm{~mL})$ was stirred for $1 \mathrm{~h}$. The solution was then evaporated to 
dryness, giving a bright yellow solid. $2\left(\mathrm{C}_{63} \mathrm{H}_{112} \mathrm{O}_{35}\right) \cdot\left(\mathrm{C}_{11} \mathrm{H}_{10} \mathrm{MoO}_{4}\right)$ $\cdot 6 \mathrm{H}_{2} \mathrm{O}$ (3269.3): calcd. C 50.33, H 7.58, Mo 2.93; found C 50.33, $\mathrm{H} 7.95$, Mo 2.60. TGA up to $150{ }^{\circ} \mathrm{C}$ revealed a sample weight loss of $3.3 \%$ (calcd.: for loss of $6 \mathrm{H}_{2} \mathrm{O}, 3.3 \%$ ). FTIR $(\mathrm{KBr}): \tilde{v}=3450$ (m), 2984 (m), 2932 (s), 2834 (m), 1963 (m, $v_{\mathrm{CO}}$ ), 1910 (sh, $v_{\mathrm{CO}}$ ), $1889\left(\mathrm{~m}, v_{\mathrm{CO}}\right), 1723\left(\mathrm{~m}, v_{\mathrm{CO}}\right.$ of $\left.\mathrm{COOH}\right), 1630(\mathrm{~m}), 1461(\mathrm{~m}), 1405$ (w), 1368 (m), 1324 (w), 1305 (w), 1261 (w), 1230 (m), 1196 (s), 1162 (vs), 1144 (vs), 1109 (vs), 1089 (vs), 1070 (vs), 1039 (vs), 970 (m), $652(\mathrm{~m}), 912(\mathrm{~m}), 855(\mathrm{~m}), 755(\mathrm{~m}), 706(\mathrm{~m}), 604(\mathrm{w}), 549(\mathrm{~m})$, 528 (m), 355 (w), 346 (w), 307 (sh), $301(\mathrm{~m}) \mathrm{cm}^{-1} \cdot{ }^{13} \mathrm{C}\left\{{ }^{1} \mathrm{H}\right\} \mathrm{CP}$ MAS NMR: $\delta=99.9,96.2,92.7$ (TRIMEB, C1), 85.6, 83.2, 82.5, 81.2 78.6, 76.8 (TRIMEB, C2,3,4), 72.6, 71.8, 70.4, 69.9 (TRIMEB, C5,6), 63.2, 61.5, 60.8, 60.0, 59.4, 57.8, 56.7, 54.0 (TRIMEB, OMe) ppm.

及-CD·2: A solution of phenylalanine derivative 2 (100 mg, $0.22 \mathrm{mmol})$ in ethanol $(15 \mathrm{~mL})$ was added to a solution of $\beta-\mathrm{CD}$ $(585 \mathrm{mg}, 0.44 \mathrm{mmol})$ in water $(10 \mathrm{~mL})$ at room temperature, and the resultant mixture was stirred for $20 \mathrm{~min}$. During this period, a pale green colour developed. Solid $\beta-\mathrm{CD} \cdot 2$ was isolated by freezedrying. $2\left(\mathrm{C}_{42} \mathrm{H}_{70} \mathrm{O}_{35}\right) \cdot\left(\mathrm{C}_{21} \mathrm{H}_{21} \mathrm{MoNO}_{5}\right) \cdot 20 \mathrm{H}_{2} \mathrm{O}$ (3093.6): calcd. $\mathrm{C}$ 40.77, H 6.55, N 0.45, Mo 3.10; found C 40.59, H 6.22, N 0.39, Mo 3.22. TGA up to $160{ }^{\circ} \mathrm{C}$ revealed a sample weight loss of $8.5 \%$ (calcd.: for loss of $20 \mathrm{H}_{2} \mathrm{O}, 11.6 \%$; for loss of $14 \mathrm{H}_{2} \mathrm{O}, 8.4 \%$ ). FTIR $(\mathrm{KBr}): \tilde{v}=3349(\mathrm{~s}), 2926(\mathrm{~s}), 1956\left(\mathrm{~m}, \mathrm{v}_{\mathrm{CO}}\right), 1873\left(\mathrm{~m}, \mathrm{v}_{\mathrm{CO}}\right), 1733$ (m, $v_{\mathrm{CO}}$ of COOMe), $1652(\mathrm{~m}), 1418(\mathrm{~m}), 1368(\mathrm{~m}), 1336(\mathrm{~m}), 1302$ (m), 1267 (m), 1246 (m), 1197 (m), 1158 (vs), 1081 (vs), 1058 (vs), 1030 (vs), 1003 (vs), 946 (m), 939 (m), 859 (m), 756 (m), 734 (m), $706(\mathrm{~m}), 668(\mathrm{~m}), 653(\mathrm{w}), 609(\mathrm{~m}), 579(\mathrm{~m}), 529(\mathrm{~m}), 479(\mathrm{w}), 445$ (w), $410(\mathrm{w}), 357(\mathrm{w}) \mathrm{cm}^{-1} \cdot{ }^{13} \mathrm{C}\left\{{ }^{1} \mathrm{H}\right\}$ CP MAS NMR: $\delta=\approx 129$ (very weak; guest, $C_{\mathrm{Ar}}$ ), $103.4(\beta-\mathrm{CD}, \mathrm{C} 1), 81.4$ ( $\left.\beta-\mathrm{CD}, \mathrm{C} 4\right), 72.8$ ( $\beta$-CD, C2,3,5), 60.6 ( $\beta$-CD, C6), 53.6 (weak; guest, OMe) ppm.

TRIMEB·2: The phenylalanine derivative $2(80 \mathrm{mg}, 0.17 \mathrm{mmol})$ was added stepwise to a solution of TRIMEB (247 mg, $0.17 \mathrm{mmol})$ in dichloromethane $(4 \mathrm{~mL})$, allowing each fraction to dissolve before adding the next. The mixture was stirred for $1 \mathrm{~h}$ and then evaporated to dryness under reduced pressure to obtain a bright yellow solid. $\left(\mathrm{C}_{63} \mathrm{H}_{112} \mathrm{O}_{35}\right) \cdot\left(\mathrm{C}_{21} \mathrm{H}_{21} \mathrm{MoNO}_{5}\right) \cdot \mathrm{H}_{2} \mathrm{O}$ (1910.9): calcd. C 52.80, H 7.12, N 0.73; Mo 5.02; found C 52.80, H 7.16, N 0.50, Mo 4.80. TGA up to $150{ }^{\circ} \mathrm{C}$ revealed a sample weight loss of $1.3 \%$ (calcd.: for loss of $\left.1 \mathrm{H}_{2} \mathrm{O}, 0.9 \%\right)$. FTIR $(\mathrm{KBr}): \tilde{v}=3307\left(\mathrm{~m}, v_{\mathrm{NH}}\right), 3089$ $(\mathrm{m}), 2984(\mathrm{~m}), 2931(\mathrm{~s}), 2841(\mathrm{~m}), 1949\left(\mathrm{~s}, v_{\mathrm{CO}}\right), 1869\left(\mathrm{~s}, v_{\mathrm{CO}}\right), 1747$ $\left(\mathrm{m}, v_{\mathrm{CO}}\right.$ of COOMe), $1660(\mathrm{~m}), 1539(\mathrm{~m}$, amide II), $1460(\mathrm{~m}), 1367$ (m), 1307 (m), 1262 (m), 1195 (s), 1162 (vs), 1143 (vs), 1109 (vs), 1090 (vs), 1073 (vs), 1034 (vs), 970 (s), 950 (s), 911 (m), 854 (m), 813 (w), 753 (m), 703 (m), 659 (w), 550 (m), 533 (m), 505 (w), $477(\mathrm{w}), 348(\mathrm{w}) \mathrm{cm}^{-1} \cdot{ }^{13} \mathrm{C}\left\{{ }^{1} \mathrm{H}\right\}$ CP MAS NMR: $\delta=170.9$ (guest, COOMe), 162.0 (guest, $C O N H$ ), 128.3 (guest, $C_{\text {Ar }}$ ), 99.3 (TRIMEB, C1), 92 (guest, $C_{\mathrm{Cp}^{\prime}}$ ), 71.0 (TRIMEB, C2,3,4), 62.2 (TRIMEB, C5,6), 60.3, 57.8 (TRIMEB, OMe), 51.7 (guest, OMe), 40.2 (guest, $C_{\text {allyl }}$ ), 35.4 (guest, $\mathrm{CH}_{2}$ ) ppm.

X-ray Crystallographic Data Collection and Refinement: A suitable single crystal of $\mathbf{1}$ was manually harvested from the crystallisation vial and mounted on a Hampton Research CryoLoop using FOMBLIN Y perfluoropolyether vacuum oil (LVAC 25/6) purchased from Aldrich ${ }^{[49]}$ with the help of a Stemi 2000 stereomicroscope equipped with Carl Zeiss lenses. Data were collected at 180(2) K on a Bruker X8 Kappa APEX II CCD area-detector diffractometer (Mo- $K_{\alpha}$ graphite-monochromated radiation, $\lambda=0.71073 \AA$ ) controlled by the APEX2 software package, ${ }^{[50]}$ and equipped with an Oxford Cryosystems Series 700 cryostream monitored remotely using the software interface Cryopad. ${ }^{[51]}$ Images were processed using SAINT+, ${ }^{[52]}$ and data were corrected for absorption by the multiscan semiempirical method implemented in SADABS. ${ }^{[53]}$ The structure was solved using the Patterson synthesis algorithm implemented in SHELXS-97, ${ }^{[54]}$ which allowed the immediate location of the crystallographically independent molybdenum centre. All remaining non-hydrogen atoms were directly located from difference Fourier maps calculated from successive full-matrix leastsquares refinement cycles on $F^{2}$ using SHELXL-97. ${ }^{[54 a, 55]}$ Nonhydrogen atoms were successfully refined using anisotropic displacement parameters.

Hydrogen atoms bound to carbon were located at their idealised positions using appropriate HFIX instructions in SHELXL (43 for the aromatic substituted $\mathrm{Cp}$ ring, 13 and 23 for the atoms belonging to the $\eta^{3}$-allyl moiety) and included in subsequent refinement cycles in riding-motion approximation with isotropic thermal displacement parameters $\left(U_{\text {iso }}\right)$ fixed at $1.2 U_{\text {eq }}$ of the attached carbon atom. The hydrogen atom associated with the carboxylic acid group was markedly visible in difference Fourier maps. These maps further showed that both of the oxygen atoms in this group (O1 and $\mathrm{O} 2)$ could be protonated. In this way, two hydrogen atoms (H1A and $\mathrm{H} 2 \mathrm{~A}$ ) were included in the final structural model with fixed occupancy of $50 \%$ each and restrained by the use of the HFIX 147 instruction in SHELXL. The isotropic thermal displacement parameters associated with these hydrogen atoms were fixed at $1.5 U_{\text {eq }}$ of the parent oxygen atom.

The last difference Fourier map synthesis showed the highest peak $\left(0.420 \mathrm{e}^{-3}\right)$ and deepest hole $\left(-0.369 \mathrm{e}^{-3}\right)$ located at 0.96 and $0.85 \AA$ from Mo1, respectively. Information concerning crystallographic data collection and structure refinement details is summarised in Table 3. Structural drawings were created using Crystal Impact Diamond. ${ }^{[56]}$

Table 3. Crystal and structure refinement data for the organometallic complex 1.

\begin{tabular}{ll}
\hline Formula & $\mathrm{C}_{11} \mathrm{H}_{10} \mathrm{MoO}_{4}$ \\
Formula weight & 302.13 \\
Crystal system & monoclinic \\
Space group & $P 2_{1} / c$ \\
$a[\AA]$ & $8.1444(5)$ \\
$b[\AA]$ & $6.6669(4)$ \\
$c[\AA]$ & $20.0614(14)$ \\
$\beta\left[{ }^{\circ}\right]$ & $100.373(3)$ \\
Volume $\left[\AA^{3}\right]$ & $1071.49(12)$ \\
$Z$ & 4 \\
$D_{\text {calcd. }}\left[\mathrm{gcm}^{-3}\right]$ & 1.873 \\
$\mu\left(\right.$ Mo- $\left.K_{a}\right)\left[\mathrm{mm}^{-1}\right]$ & 1.218 \\
Crystal size $[\mathrm{mm}]$ & $0.05 \times 0.03 \times 0.02$ \\
Crystal type & yellow blocks \\
$\theta$ range & 3.55 to 25.35 \\
Index ranges & $-9 \leq h \leq 9,-6 \leq k \leq 7,-24 \leq l \leq 24$ \\
Reflections collected & 13698 \\
Independent reflections & $1928\left(R_{\text {int }}=0.0340\right)$ \\
Completeness to $\theta=25.35^{\circ}[\%]$ & 98.8 \\
Final $R$ indices $[I>2 \sigma(I)]^{[a, b]}$ & $R 1=0.0217, w R 2=0.0451$ \\
Final $R$ indices (all data) ${ }^{[a, b]}$ & $R 1=0.0287, w R 2=0.0471$ \\
Weighting scheme ${ }^{[c]}$ & $m=0.0166, n=1.0364$ \\
Largest diff. peak and hole & 0.420 and -0.369 \\
[e $\left.\AA^{-3}\right]$ &
\end{tabular}

[a] $R 1=\Sigma|| F_{\mathrm{o}}|-| F_{\mathrm{c}}|/ \Sigma| F_{\mathrm{o}} \mid \cdot[\mathrm{b}] w R 2=\sqrt{\Sigma}\left[w\left(F_{\mathrm{o}}^{2}-F_{\mathrm{c}}^{2}\right)^{2}\right] / \Sigma\left[w\left(F_{\mathrm{o}}^{2}\right)^{2}\right]$. [c] $w=1 /\left[\sigma^{2}\left(F_{\mathrm{o}}^{2}\right)+(m P)^{2}+n P\right]$ in which $P=\left(F_{\mathrm{o}}^{2}+2 F_{\mathrm{c}}^{2}\right) / 3$.

CCDC-984808 contains the supplementary crystallographic data (including structure factors) for this paper. These data can be obtained free of charge from The Cambridge Crystallographic Data Centre via www.ccdc.cam.ac.uk/data_request/cif. 


\section{Evaluation of Antiproliferative Activity}

Cell Culture: K1735-M2 mouse melanoma cells ${ }^{[43]}$ (a kind gift from Dr. Lillian Repesh, Department of Anatomy, Microbiology and Pathology, University of Minnesota, Medical School, Duluth, USA) were grown in Dulbecco's modified Eagle's medium (DMEM) supplemented with sodium hydrogen carbonate $\left(1.5 \mathrm{gL}^{-1}\right), 10 \%$ fetal bovine serum, penicillin $\left(100 \mathrm{UmL}^{-1}\right)$ and streptomycin $\left(100 \mu \mathrm{g} \mathrm{mL}^{-1}\right)$ at $37^{\circ} \mathrm{C}$ in a humidified atmosphere of $5 \% \mathrm{CO}_{2}$. Cells were passaged by trypsinisation using standard methods; all experiments were seeded from cultures in log-phase growth.

The H9c2 cell line, originally derived from embryonic rat heart tissue using selective serial passages, ${ }^{[57]}$ was purchased from the American Tissue Type Collection (Manassas, VA; catalogue \# CRL - 1446). MDA-MB-231 is a human epithelial cell line extracted from the mammary gland, responsible for the formation of adenocarcinomas. ${ }^{[58]}$ H9c2 and MDA-MB-231 cells were cultured in DMEM as described above. Cells were fed every 2-3 days, and subcultured once reaching 70-80\% confluence.

Cell Proliferation Measurements: SRB assays ${ }^{[59]}$ were conducted to measure the effects of the compounds on the proliferation of all three cell lines, essentially as described by Holy et al. ${ }^{[60]}$ The cell lines were seeded at a concentration of $1 \times 10^{4}$ cells $\mathrm{mL}^{-1}$ in 48 -well plates, and allowed to recover for one day prior to addition of the test compound. Vehicle controls were also performed. After SRB labelling in acidic buffer, absorbance measured at $540 \mathrm{~nm}$ was proportional to the number of cells present in the dish, which is a reliable indicator of cell proliferation. Values were determined in terms of percentage of time zero (i.e., the cell mass before test compound or vehicle treatment) and compared with the control for the respective time point.

\section{Acknowledgments}

This work was partly financed by the Fundo Europeu de Desenvolvimento Regional (FEDER) through COMPETE (Programa Operacional Factores de Competitividade) and by Portuguese national funds through the Fundação para a Ciência e a Tecnologia FCT) within the projects PEst-OE/QUI/UI0070/2011, CICECO - FCOMP-01-0124-FEDER-037271 (FCT ref. PEst-C/CTM/ LA0011/2013), QOPNA - FCOMP-01-0124-FEDER-037296 (PEst C-QUI/UI0062/2013) and FCOMP-01-0124-FEDER-029779 (FCT ref. PTDC/QEQ-SUP/1906/2012). The authors further wish to thank FCT for specific funding towards the purchase of the singlecrystal diffractometer.

[1] M. Cousins, M. L. H. Green, J. Chem. Soc. 1963, 889.

[2] R. B. King, Inorg. Chem. 1966, 5, 2242.

[3] A. Davison, W. C. Rode, Inorg. Chem. 1967, 6, 2124.

[4] J. W. Faller, M. J. Incorvia, Inorg. Chem. 1968, 7, 840.

[5] R. G. Hayter, J. Organomet. Chem. 1968, 13, P1-P3.

[6] J. W. Faller, C.-C. Chen, M. J. Mattina, A. Jakubowski, J. Organomet. Chem. 1973, 52, 361-386.

[7] J. R. Ascenso, C. G. de Azevedo, I. S. Gonçalves, E. Herdtweck, D. S. Moreno, M. Pessanha, C. C. Romão, Organometallics 1995, 14, 3901-3919.

[8] F. Pammer, Y. Sun, W. R. Thiel, Organometallics 2008, 27, 1015-1018.

[9] J. Honzíček, A. Mukhopadhyay, C. Bonifacio, C. C. Romão, J. Organomet. Chem. 2010, 695, 680-686.

[10] S. S. Braga, I. S. Gonçalves, A. D. Lopes, M. Pillinger, J. Rocha, C. C. Romão, J. J. C. Teixeira-Dias, J. Chem. Soc., Dalton Trans. 2000, 2964-2968.
[11] J. Honzíček, A. Mukhopadhyay, T. Santos-Silva, M. J. Romão, C. C. Romão, Organometallics 2009, 28, 2871-2879.

[12] a) J. W. Faller, B. C. Whitmore, Organometallics 1986, 5, 752 755; b) S. Kang, Bull. Korean Chem. Soc. 1989, 10, 554-559; c) A. Ariafard, S. Bi, Z. Lin, Organometallics 2005, 24, 22412244; d) C. Limberg, A. J. Downs, T. M. Greene, T. Wistuba, Eur. J. Inorg. Chem. 2001, 2613-2618; e) T. E. Bitterwolf, J. T. Bays, B. Scallorn, C. A. Weiss, M. W. George, I. G. Virrels, J. C. Linehan, C. R. Yonker, Eur. J. Inorg. Chem. 2001, 2619-2624.

[13] a) J. R. Ascenso, C. G. de Azevedo, I. S. Gonçalves, E. Herdtweck, D. S. Moreno, C. C. Romão, J. Zühlke, Organometallics 1994, 13, 429-431; b) I. S. Gonçalves, C. C. Romão, J. Organomet. Chem. 1995, 486, 155-161; c) I. S. Gonçalves, P. Ribeiro-Claro, C. C. Romão, B. Royo, Z. M. Tavares, J. Organomet. Chem. 2002, 648, 270-279; d) J. Honzíček, J. Vinklárek, M. Erben, J. Lodinský, L. Dostál, Z. Padělková, Organometallics 2013, 32, 3502-3511.

[14] a) C.-L. Li, R.-S. Liu, Chem. Rev. 2000, 100, 3127-3162, and references cited therein; b) A. Alcudia, R. G. Arrayás, L. S. Liebeskind, J. Org. Chem. 2002, 67, 5773-5778, and references cited therein.

[15] P. Neves, C. C. L. Pereira, F. A. A. Paz, S. Gago, M. Pillinger, C. M. Silva, A. A. Valente, C. C. Romão, I. S. Gonçalves, J. Organomet. Chem. 2010, 695, 2311-2319.

[16] P. M. Reis, C. A. Gamelas, J. A. Brito, N. Saffon, M. Gómez, B. Royo, Eur. J. Inorg. Chem. 2011, 666-673.

[17] D. R. van Staveren, T. Weyhermüller, N. Metzler-Nolte, Organometallics 2000, 19, 3730-3735.

[18] a) M. S. Saraiva, S. Quintal, F. C. M. Portugal, T. A. Lopes, V. Félix, J. M. F. Nogueira, M. Meireles, M. G. B. Drew, M. J. Calhorda, J. Organomet. Chem. 2008, 693, 3411-3418; b) D. Bandarra, M. Lopes, T. Lopes, J. Almeida, M. S. Saraiva, M. Vasconcellos-Dias, C. D. Nunes, V. Félix, P. Brandão, P. D. Vaz, M. Meireles, M. J. Calhorda, J. Inorg. Biochem. 2010, 104, 1171-1177.

[19] F. Hapiot, S. Tilloy, E. Monflier, Chem. Rev. 2006, 106, 767781.

[20] a) A. C. Gomes, S. M. Bruno, C. Tomé, A. A. Valente, M. Pillinger, M. Abrantes, I. S. Gonçalves, J. Organomet. Chem. 2013, 730, 116-122; b) S. Lima, I. S. Gonçalves, P. RibeiroClaro, M. Pillinger, A. D. Lopes, P. Ferreira, J. J. C. TeixeiraDias, J. Rocha, C. C. Romão, Organometallics 2001, 20, 21912197.

[21] S. S. Braga, S. Gago, J. D. Seixas, A. A. Valente, M. Pillinger, T. M. Santos, I. S. Gonçalves, C. C. Romão, Inorg. Chim. Acta 2006, 359, 4757-4764.

[22] S. S. Balula, A. C. Coelho, S. S. Braga, A. Hazell, A. A. Valente, M. Pillinger, J. D. Seixas, C. C. Romão, I. S. Gonçalves, Organometallics 2007, 26, 6857-6863.

[23] a) S. S. Braga, F. A. A. Paz, M. Pillinger, J. D. Seixas, C. C. Romão, I. S. Gonçalves, Eur. J. Inorg. Chem. 2006, 1662-1669; b) C. C. L. Pereira, S. S. Braga, F. A. A. Paz, M. Pillinger, J. Klinowski, I. S. Gonçalves, Eur. J. Inorg. Chem. 2006, 42784288.

[24] C. C. L. Pereira, C. V. Diogo, A. Burgeiro, P. J. Oliveira, M. P. M. Marques, S. S. Braga, F. A. A. Paz, M. Pillinger, I. S. Gonçalves, Organometallics 2008, 27, 4948-4956.

[25] a) F. J. Otero-Espinar, J. J. Torres-Labandeira, C. AlvarezLorenzo, J. Blanco-Mendez, J. Drug Delivery Sci. Technol. 2010, 20, 289-301; b) R. L. Carrier, L. A. Miller, I. Ahmed, J. Controlled Release 2007, 123, 78-99.

[26] K. Uekama, F. Hirayama, T. Irie, Chem. Rev. 1998, 98, 20452076.

[27] F. Hirayama, K. Uekama, Adv. Drug Deliv. Rev. 1999, 36, 125141.

[28] a) M. E. Davis, M. E. Brewster, Nat. Rev. Drug Discovery 2004, 3, 1023-1035; b) A. M. Krause-Heuer, M. P. Grant, N. Orkey, J. R. Aldrich-Wright, Aust. J. Chem. 2008, 61, 675-681; c) F. A. A. Paz, S. S. Braga, in: Organometallic Compounds: Prep- 
aration, Structure and Properties (Ed.: H. F. Chin), Novascience Publishers, Hauppauge, NY, 2010, p. 465-481.

[29] K. Cal, K. Centkowska, Eur. J. Pharm. Biopharm. 2008, 68, 467-478

[30] Mercury, CSD 2.0, New Features for the Visualization and Investigation of Crystal Structures: C. F. Macrae, I. J. Bruno, J. A. Chisholm, P. R. Edgington, P. McCabe, E. Pidcock, L. Rodriguez-Monge, R. Taylor, J. van de Streek, P. A. Wood, J. Appl. Crystallogr. 2008, 41, 466.

[31] a) F. H. Allen, Acta Crystallogr., Sect. B: Struct. Sci. 2002, 58, 380-388; b) F. H. Allen, W. D. S. Motherwell, Acta Crystallogr., Sect. B: Struct. Sci. 2002, 58, 407-422.

[32] J. W. Faller, D. F. Chodosh, D. Katahira, J. Organomet. Chem. 1980, 187, 227-231.

[33] W. E. Vanarsdale, J. K. Kochi, J. Organomet. Chem. 1986, 317, 215-232

[34] J. Honzíček, P. Kratochvíl, J. Vinklárek, A. Eisner, Z. Padělková, Organometallics 2012, 31, 2193-2202.

[35] J. Grell, J. Bernstein, G. Tinhofer, Acta Crystallogr., Sect. B: Struct. Sci. 1999, 55, 1030-1043.

[36] S. S. Braga, M. P. M. Marques, J. B. Sousa, M. Pillinger, J. J. C. Teixeira-Dias, I. S. Gonçalves, J. Organomet. Chem. 2005, 690, 2905-2912.

[37] C. C. L. Pereira, M. Nolasco, S. S. Braga, F. A. A. Paz, P. Ribeiro-Claro, M. Pillinger, I. S. Gonçalves, Organometallics 2007, 26, 4220-4228.

[38] J. A. Fernandes, S. S. Braga, R. A. S. Ferreira, M. Pillinger, L. D. Carlos, P. Ribeiro-Claro, I. S. Gonçalves, J. Inclusion Phenom. Macrocyclic Chem. 2006, 55, 329-333.

[39] M. R. Caira, Rev. Roum. Chim. 2001, 46, 371-386.

[40] S. Immel, F. W. Lichtenthaler, Starch/Staerke 1996, 48, 225232.

[41] a) M. J. Gidley, S. M. Bociek, J. Am. Chem. Soc. 1988, 110, 3820-3829; b) S. J. Heyes, N. J. Clayden, C. M. Dobson, Carbohydr. Res. 1992, 233, 1-14.

[42] Y. P. Keepers, P. E. Pizao, G. J. Peters, J. Ark-Otte, B. Winograd, H. M. Pinedo, Eur. J. Cancer 1991, 27, 897-900.

[43] G. C. Pereira, A. F. Branco, J. A. Matos, S. L. Pereira, D. Parke, E. L. Perkins, T. L. Serafim, V. A. Sardão, M. S. Santos, A. J. Moreno, J. Holy, P. J. Oliveira, J. Pharmacol. Exp. Ther. 2007, $323,636-649$.

[44] T. L. Serafim, P. J. Oliveira, V. A. Sardão, E. L. Perkins, D. Parke, J. Holy, Cancer Chemother. Pharmacol. 2008, 61, 10071018.
[45] a) M. Lacroix, G. Leclercq, Breast Cancer Res. Treat. 2004, 83, 249-289; b) H. Rochefort, M. Glondu, M. E. Sahla, N. Platet, M. Garcia, Endocr-Relat. Cancer 2003, 10, 261-266.

[46] a) S. Turakhia, C. D. Venkatakrishnan, K. Dunsmore, H. Wong, P. Kuppusamy, J. L. Zweier, G. Ilangovan, Am. J. Physiol. Heart. Circ. Physiol. 2007, 293, H3111-121; b) J. L. V. Reeve, E. Szegezdi, S. E. Logue, T. N. Chonghaile, T. O'Brien, T. Ritter, A. Samali, J. Cell. Mol. Med. 2007, 11, 509-520.

[47] S. S. Braga, C. V. Diogo, T. M. Santos, J. Marques, P. J. Oliveira, E. Heister, F. A. A. Paz, M. P. M. Marques, Biometals 2014, 27, 507-525.

[48] A. I. Ramos, T. M. Braga, P. Silva, J. A. Fernandes, P. RibeiroClaro, M. F. S. Lopes, F. A. A. Paz, S. S. Braga, CrystEngComm 2013, 15, 2822-2834.

[49] T. Kottke, D. Stalke, J. Appl. Crystallogr. 1993, 26, 615-619.

[50] APEX2, Data Collection Software, version 2.1-RC13, Bruker AXS, Delft, The Netherlands, 2006.

[51] Cryopad, Remote Monitoring and Control, version 1.451, Oxford Cryosystems, Oxford, UK, 2006.

[52] SAINT+, Data Integration Engine, version 7.23a, Bruker AXS, Madison, WI, USA, 2005.

[53] G. M. Sheldrick, SADABS, version 2.01, Bruker/Siemens, Area Detector Absorption Correction Program, 1998, Bruker AXS, Madison, Wisconsin, USA.

[54] a) G. M. Sheldrick, Acta Crystallogr., Sect. A: Found. Crystallogr. 2008, 64, 112-122; b) G. M. Sheldrick, SHELXS-97, Program for Crystal Structure Solution, University of Göttingen, Germany, 1997.

[55] G. M. Sheldrick, SHELXL-97, Program for Crystal Structure Refinement, University of Göttingen, Germany, 1997.

[56] K. Brandenburg, DIAMOND, version 3.2f, Crystal Impact GbR, Bonn, Germany, 1997-2010.

[57] B. W. Kimes, B. L. Brandt, Exp. Cell Res. 1976, 98, 367-381.

[58] C. M. Taylor, B. Blanchard, D. T. Zava, Cancer Res. 1984, 44, $1409-1414$.

[59] P. Skehan, R. Storeng, D. Scudiero, A. Monks, J. McMahan, D. Vistica, J. T. Warren, H. Bokesch, S. Kenny, M. R. Boyd, J. Natl. Cancer Inst. 1990, 82, 1107-1112.

[60] J. Holy, G. Lamont, E. Perkins, BMC Cell Biol. 2006, 7, 13.

Received: June 13, 2014

Published Online: August 19, 2014 